\title{
Bagehot for Central Bankers
}

\author{
Laurent Le Maux*
}

\section{Working Paper No. 147}

\author{
February $10^{\text {th }}, 2021$
}

\begin{abstract}
Walter Bagehot (1873) published his famous book, Lombard Street, almost 150 years ago. The adage "lending freely against good collateral at a penalty rate" is associated with his name and his book has always been set on a pedestal and is still considered as the leading reference on the role of lender of last resort. Nonetheless, without a clear understanding of the theoretical grounds and the institutional features of the British banking system, any interpretation of Bagehot's writings remains vague if not misleading - which is worrisome if they are supposed to provide a guideline for policy makers. The purpose of the present paper is to determine whether Bagehot's recommendation remains relevant for modern central bankers or whether it was indigenous to the monetary and banking architecture of Victorian times.
\end{abstract}

\section{https://doi.org/10.36687/inetwp147}

JEL codes: B1, E5

Key words: Central Banking, Lender of Last Resort

\footnotetext{
${ }^{*}$ Professor in economics at University of Western Brittany and research professor at University of Paris Panthéon La Sorbonne, France. Email: lemaux.laurent@gmail.com. I would like to thank Emmanuel Carré and Perry Mehrling for their helpful comments. All errors and omissions are my own.
} 


\section{The 1844 Bank Act and the Peel system}

1.1. The rule of issue

1.2. The monopoly of banknote issue

1.3. The separation of the Bank of England and the new discount policy

\section{The Bank policy and Bagehot's position}

2.1. The banking reserve

2.2. The Bank rate

2.3. Lending of last resort

\section{Bagehot's rule}

3.1. Lending of last resort and Bagehot

3.2. The interbank level: interpretations and discussions

3.3. The international level: "A uniform remedy for many diseases"

\subsubsection{Diseases and factors of drains}

\subsubsection{Bagehot's three assertions}

3.3.3. Tooke's three propositions

Walter Bagehot (1873) published his famous book, Lombard Street, almost 150 years ago. The adage "lending freely against good collateral at a penalty rate" is associated in the literature with his name and his book has always been set on a pedestal and is still considered as the leading reference on the role of lender of last resort. In the academic literature, among others, Sayers (1951, p. 109) considered that Lombard Street "settles once and for all the question of how the Bank [of England] should behave in a crisis"; Meltzer (1986, p. 81) that, even if the present-day monetary regime differs from the gold specie standard, "these and other changes do not reduce the relevance of the principles that Bagehot presented"; and Giannini $(2011$, pp. 87, 90) that Bagehot preached a "Copernican revolution" and, "to this day, [Bagehot's theories] are often cited as the essence of central banking." In lectures by central bank's officials, among others, Madigan (2009, pp. 169, 187) claimed that "Bagehot's dictum is well founded" and "continues to provide a useful framework for designing central bank actions for combating a financial crisis." In this respect, Bernanke (2013, p. 83) deemed that, during the 2007-09 financial crisis, 
"the Federal Reserve, responding in the way Bagehot would have had it respond, [...] stood as a backstop lender." More recently, the massive intervention of central banks during the 2020 COVID crisis calls for further investigation of their role as lender of last resort within the banking and financial system.

Bagehot's recommendations were enunciated under the classical specie regime and more specifically under the particular banking architecture enacted by the British parliament in 1844the Peel system. While currency doctrine governing the 1844 Act gave no scope for the lender of last resort, the Chancellor of the Exchequer authorized the Bank of England to suspend the statutory rule of issue in 1847, 1857, and 1866. After the 1866 crisis, Bagehot's intention was finally to reconcile the Peel system with the action of the Bank of England as lender of last resort. As is well known, the former Bank director Thomson Hankey excoriated an article in the Economist (Bagehot, 1866f) claiming the Bank's role was to respond to demand for banking reserve during banking panics. Addressing the question of moral hazard Hankey (1867, p. 25) deemed that Bagehot's rule was "the most mischievous doctrine ever broached" in Britain. But behind all the bluster, the differences between the two were not that great: Bagehot (1873, pp. 32934) repeated that his aim was to maintain the Peel system even if it involved tweaking it here and there, while Hankey (1867) just wished to keep it intact.

Unfortunately, the sound and the fury of the Bagehot-Hankey quarrel has long distracted attention from more serious and intense theoretical debates about money and banking in Britain from the 1840 to the 1857 parliamentary inquiries, in which Thomas Tooke played a crucial role. ${ }^{1}$ From the 1840 to the 1857 volumes of his History of Prices, Tooke, together with John Stuart Mill (1844, 1848) and John Fullarton (1845), built a unified theoretical framework of money and banking. Extending the lender-of-last-resort analysis initiated in Thornton's (1802) Paper Credit, Tooke's final contributions (Tooke, 1848, 1857) and declarations (PP Commons 1848, PP Lords 1848) carried classical central banking theory forward (Le Maux, 2020). On this theoretical basis, Tooke called for the repeal of the letter and spirit of the 1844 Act and plainly advocated the need for a lender of last resort. While the literature on the classical theory of lender of last resort focuses on Bagehot's analysis and includes Hankey's response, the perspective needs to be widened to take in British monetary debates more generally. It also needs to consider the British gold specie regime

\footnotetext{
${ }^{1}$ Parliamentary Papers (PP hereafter): PP (1832), PP (1840), PP (Commons 1848), PP (Lords 1848) and PP (1857). Then, Bagehot (1873) came after the theoretical battle which notably opposed the banking school and the currency school. Contributions from the banking school included Thomas Tooke (1840, PP 1840, 1844, 1848, PP Commons 1848, PP Lords 1848), John Fullarton (1845), John Stuart Mill (1844, 1848, PP 1857), Tooke and William Newmarch (1857), and Newmarch (PP 1857, 1866). The principal contributions from the currency school were from Samuel Loyd (PP 1840, 1844, PP Lords 1848, 1857, PP 1857), George Norman (PP 1840, 1841, PP Lords 1848), and Robert Torrens $(1844,1848,1857)$. On the British monetary debate, see Viner (1937), Rist (1940), Wood (1939), Horsefield (1944), Fetter (1965), Laidler (1972), and Arnon (2011). Mehrling (2019) also focuses on the theoretical debate between the banking school and the currency school and puts the quarrel between Bagehot and Hankey in the background.
} 
generally from 1821 onwards, and the two different central banking systems within that periodthe 'Old system' between 1821 and 1844 and the 'Peel system' after 1844 (Le Maux, 2018).

While the difference between Tooke and Bagehot in terms of theory is not commonly acknowledged, correlatively the action of the Bank of England during the 1825 crisis is also disregarded. The literature on financial history often refers to the 1866 crisis as a turning point in the history of central banking in Britain (Schwartz, 1986; Bordo, 1998; Flandreau and Ugolini, 2013). Such an interpretation supports Bagehot's (1873, p. 64) assertion that the Bank acted in the best way during the 1866 panic. Earlier, Tooke (1848, pp. 329-48) had emphasized the significance of the Bank's intervention during the 1825 panic. Even Bagehot (1873, p. 202) himself acknowledged that "the success of the Bank" in resolving the 1825 panic "was owing to its complete adoption of right principles." Not without contradiction, Bagehot (1873, p. 108) added that the management of the 1825 crisis revealed "the worst misconduct of the Bank." In fact, Bagehot did not lose sight of his main purpose, which was to show that the lender-of-last-resort's role was compatible with the Peel system and, in this respect, that the Bank's conduct during the 1866 crisis had been exemplary.

Beyond the historical context of Bagehot's Lombard Street, the difficulties begin when the economist attempts to understand its theoretical underpinnings. Interestingly John Maynard Keynes (1915, p. 372) thought that the "theoretical parts of Lombard Street" were "not very good" and "rather confused and rather superficial." Bagehot himself repeatedly stated that he did not delve into monetary and banking theory but rested his arguments on experience. "The only plan is to set abstract theory for the moment aside, and look at the palpable facts" (Bagehot, 1866c, p. 101; see also, 1864b, p. 428; 1864f, pp. 456-7; 1864g, p. 467; 1873, pp. 2, 45, 84). On the one hand, Bagehot (1873, p. 84) claimed that he was "only narrating unquestionable history" - even though the history he narrated was open to discussion. On the other hand, his intention was not to "meddle" with monetary and banking "theory"-even though Bagehot (1848) had earlier supported the currency doctrine which had contributed to shaping British banking architecture in 1844. Finally, Bagehot (1873, p. 161) contended that the theoretical "discussion was terminated by the Act of 1844 " - even though this was far from being the case as shown by the 1848 and 1857 parliamentary inquiries, the criticism of the Peel system in the Lords' Report (PP Lords 1848), and the controversy between Tooke $(1848,1857)$ and Torrens $(1848,1857)$.

Bagehot's disinclination to propose an overall theoretical model of money and banking does not help the economist to reconstruct Bagehot's thinking on central banking. But this difficulty needs to be overcome. Accordingly I shall consider (1) all Bagehot's economic writings from the late 1840 s to the mid-1870s, a period during which period Bagehot did not significantly depart from the currency doctrine but did suggest some amendments; (2) consequently, the contribution of the currency school's writers, as well as official statements to the parliamentary inquiries; (3) finally, the Peel system, defined as the overall institutional framework resulting from the 1844 Act, namely, the separation of the Bank of England into two departments, and the 'new' discount policy 
of the banking department from September 1844 onward. ${ }^{2}$ In addition, I shall refer to classical central banking theory and focus on Tooke's - rather than Thornton's - contribution inasmuch as it dealt with the Peel system that Bagehot's contribution addressed. I shall also refer to present-day interpretations of Bagehot's rule. ${ }^{3}$ As several excerpts from Lombard Street have often been quoted in the literature, I shall reveal the institutional and theoretical framework of which they are part, and explore within bounds the historical background to Bagehot's writings.

The spirit of Goodhart's (1994) article has inspired the title and substance of the present one. Rational expectation theory and game theory in the late twentieth century in the United States and Europe determined the analysis and practice of central banking. Similarly, in the early nineteenth century Britain, quantity theory and the currency principle contributed to the growing opinion in the Club of Political Economy in London and finally to the adoption of the 1844 Act presented by the Prime Minister Robert Peel. Without a clear understanding of the theoretical grounds and the institutional features of the British banking system throughout Victorian times, any interpretation of Bagehot's writings remains vague if not misleading - which is worrisome if they are supposed to provide a guideline for policy makers. Finally, the purpose of the present paper is to determine whether Bagehot's recommendation remains relevant for modern central bankers or whether it was indigenous to the monetary and banking architecture of Victorian times.

With this in mind, this article proceeds as follows. Section 1 presents the theoretical and institutional features of the Peel system. It shows how Bagehot's words echoed the letter of the 1844 Act, to include the rule of issue, banknote monopoly, and separation of the Bank of England. It also shows that Bagehot accepted the spirit of the 1844 Act, namely, the new or active discount policy of the Bank. Section 2 examines how Bagehot advocated retaining the Peel system and attempted to find palliatives, namely, the holding of large banking reserves (actually in the same ratio as suggested by the Bank directors), the setting of the Bank rate (similar in fact to the policy conducted by the Bank directors from September 1844 onwards), and lending of last resort (in much the same way as the Bank did intervene from the 1847 crisis onward). Section 3 examines Bagehot's rule of the very high interest rate. It surveys the present-day literature and discussions about the aim of Bagehot's rule - mainly at the interbank level. In addition, it revisits the classical

\footnotetext{
${ }^{2}$ Respectively, the references are: (1) Lombard Street (Bagehot, 1873), various articles (Bagehot, 1848, 1858), editorial articles published in the Economist (Bagehot, 1857a-h, 1861, 1864a-h, 1865, 1866a-g, 1867a-b, 1869a-b, 1871, 1874, 1875, 1876), and parliamentary testimonies (PP 1875); (2) publications and parliamentary testimonies of the currency school members (Loyd, PP 1840, 1844, PP Lords 1848, 1857, PP 1857; Norman, PP 1840, 1841, PP Lords 1848; Torrens, 1844, 1848, 1857); (3) discourses and parliamentary testimonies from officials (Peel, 1844; Cotton, PP Commons 1848, PP Lords 1848; Morris, PP Commons 1848, PP Lords 1848).

${ }^{3}$ With regard to present-day literature on the lender of last resort, one may refer to Humphrey $(1975,1989)$, Hirsh (1977), Guttentag and Herring (1983), Humphrey and Keleher (1984), Claassen (1985), Meltzer (1986), Hetzel (1987), Goodhart (1988, 1999), Bordo (1990, 2014), Corrigan (1990), Kaufman (1991), Shend (1991), Freeman (1996), Moore (1996, 1999), Giannini (1999), Freixas et al. (2000), Repullo (2000), Sleet and Smith (2000), Wood (2000), Antinolfi, Huybens and Keister (2001), Freixas, Parigi and Rochet (2004), Laidler (2004a, 2004b), Rochet and Vives (2004), Repello (2005), Martin (2006, 2009), Santos (2006), Milne and Wood (2008), Madigan (2009), and Castiglionesi and Wagner (2012), Hogan, Le and Salter (2015).
} 
monetary theory developed by Thomas Tooke about the different kinds of drain and central bank responses-especially at international level. Therefore, Bagehot's recommendation will be weighed here and there against the Tooke's analysis and contemporary contributions.

\section{The 1844 Bank Act and the Peel system}

Bagehot wrote both positively and normatively on money and banking from the late 1840s to the mid-1870s, a period that coincided with the Peel system. So the understanding of the Peel system appears crucial. The three main components of the 1844 Act are briefly recalled: the rule of issue (1.1), the banknote monopoly (1.2), and the separation of the Bank of England into issue and banking departments (1.3). I shall refer to classical central banking practice from the 1821 return to convertibility until the 1844 banking legislation as the 'Old system', and to the new discount policy from September 1844 as the 'Peel system'.

\subsection{The rule of issue}

The first component of the 1844 Act was the statutory rule of issue, known as the currency principle, which stated that the circulation of all banknotes should vary in quantity with the metallic reserve. The currency principle was supposed to be the sole mechanism by which the circulation of banknotes would vary in value with gold and would therefore achieve the monetary objective of convertibility into specie. Otherwise, the price-specie-flow mechanism was supposed to take place, that is, the issue of banknotes not covered by gold was supposed to be necessarily in excess, generating a rise in prices and an outflow of bullion. Since his early years, Bagehot (1848, pp. 2589) endorsed the currency doctrine by restating the argument made by Torrens $(1844,1848)$, the theorist; Bagehot (1857b, pp. 326-7) also referred to Loyd (PP, 1840), the influential leader of the currency school. In addition, Bagehot (1864g, pp. 465-6) restated that the price-specie-flow mechanism was "self-acting" with a purely "metallic currency", but not with "credit currency", which was called in to supplement the metallic medium of circulation. Lastly, Bagehot (1873, pp. 116-8) did not abandon the theoretical background of his early days and, like the members of the currency school, he put convertible banknotes and inconvertible paper money on the same footing. Both kinds of issue, it was claimed, caused similar inflationary effects, generating a rise in prices in the goods markets and speculation in the securities markets.

Institutionally, the 1844 Act did not foresee that the deposits held by bankers at the banking department of the Bank of England could be another part of the high-powered medium in addition to Bank notes. Hence, the Peel system was not strictly a currency board arrangement as is often supposed in the literature, but rather an incomplete arrangement. More fundamentally, the currency principle governing the 1844 Act associated the rule, which compelled the central bank to back at the margin its issues by metallic reserve, with convertibility, which compelled any banking institution to reimburse its issue at face value and on demand in specie. Conversely, the absence

of the rule of issue was associated with the suspension of convertibility. In line with the currency 
doctrine restated by Peel (1844), Bagehot $(1873$, pp. 63, 110) amalgamated the period of restriction (1797-1821) with that of convertibility without the rule of issue (1821-1844). Nonetheless, the monetary regimes of each period were obviously different from one another. Between 1797 and 1821 , the British government authorized the suspension of convertibility into specie and Bank paper money fluctuated in value in comparison with the official Mint gold price. Between 1821 and 1844, the Bank of England, like the Bank of France, never suspended the payments of its issues at face value against specie without applying the currency principle. So it is important to make the analytical distinction between the rule of issue of banknotes and the convertibility of demand debts into specie and, correlatively, to emphasize that convertibility into specie could be effective without a rule of issue such as the currency principle.

\subsection{The monopoly of banknote issue - and decentralization of the banking reserve}

The second component of the 1844 Act allowed for the concentration of banknote issue, which ultimately led to a monopoly in the hands of the issue department of the Bank of England. Although Bagehot (1857b, pp. 333-5) described the clearing mechanism, he denied, in line with the currency doctrine, that clearings of rival bank issues could be restrictive: it was hence asserted that "the effect of the clearing-house is to make pro tanto all banks into a single bank." Later, Bagehot (1864d, pp. 441-2; 1873, pp. 98-9) did not so much provide a theoretical demonstration in favor of the monopoly of banknote issue but set forth an empirical-if not tautological-argument. Moreover, nowhere in his writings did Bagehot state that commercial banks could or should issue banknotes in the same way as they issued demand deposits. Had Bagehot stated that free competition among issuing banks was sustainable under the specie regime, he would have referred to Parnell (1827), Gilbart (1841), and Wilson (1848) but by no means to Torrens $(1844,1848)$, who basically opposed the free issue of banknotes.

On the other hand, many passages hint that Bagehot was a proponent of laissez-faire in banking. In several passages, Bagehot (1858, p. 55) claimed that the Bank of England maintained "its unnatural supremacy"; Bagehot (1866e, pp. 18-9; 1871, p. 37), that the Bank was "a result of privileges"; Bagehot (1864d, p. 441), that the source of anomaly was the "monopoly" that led the Bank "to usurp [...] the duty of retaining the bullion reserve." Beyond the apparent contradiction, Bagehot did advocate both creating a monopoly of banknote issuing (which concerned the issue department of the Bank) and decentralizing the banking reserve (which concerned the banking department as well as other commercial banks). ${ }^{4}$ Indeed, Bagehot (1873, p. 104) was nostalgic

\footnotetext{
${ }^{4}$ For Bradford (1874, p. 343), "the first" of the "fundamental ideas" of Bagehot book's is "that it is wrong, unjust, and dangerous that the whole banking reserve of the kingdom should be kept in one bank, the Banking Department of the Bank of England." Meaningfully, when Goodhart (1988, pp. 13-9), Laidler (1988, p. 102), and Selgin (1989, p. 453) point out that Bagehot advocated laissez-faire in banking, their analysis does not concern so much the defense of free issuance of banknotes but rather the insistence with which Bagehot supported the decentralization of the banking reserve. See also Arnon (2011, pp. 288, 306-7).
} 
about or "a natural system of banking" under which "there were many banks keeping their own reserve." This was a leitmotiv in Bagehot's writings. From the 1850s to the 1870s, Bagehot (1857f, p. 377; 1864d, p. 444; PP, 1875, q. 8099) repeated that if the system was "starting de novo", he "should prefer" that "each banker kept his own bullion reserve." Hence, Bagehot fully endorsed the design defended by Peel (1844, p. 47) and Hankey (1867, pp 36-7), namely: a monopoly of the supply of banknotes, decentralization of the banking reserve, and a new discount policy for the Bank. As we shall see in the remainder of the paper, these two last features are crucial for understanding of Bagehot's recommendation.

\subsection{The separation of the Bank of England and the new discount policy}

The third component (the 1st article of the 1844 Act) separated the Bank of England into two departments. The issue department held the "metallic reserve" in the form of bullion and applied the rule of issue to Bank notes. The banking department held the "banking reserve" in the form of Bank notes and had no more duty than any other commercial bank (Commons Report, PP Commons 1848, p. iv; Lords Report, PP Lords 1848, p. xxxvi). The banking department operated like any other commercial bank in three ways - which in turn, as will be detailed in the next section, determine Bagehot's rule. Firstly, it held a part of the banking reserve. The difference between the banking department and the other banks was not one of nature but of degree: it simply held a larger banking reserve. Secondly, the banking department could vary at its discretion, without any quantitative restriction, its demand liabilities in the form of deposits convertible into specie or Bank notes. What the legislator did not foresee, however, was that the status of the banking department was ambiguous. On the one hand, the banking department was supposed to work like any other bank; on the other hand, its liabilities in the form of deposits were notably held by London and provincial bankers as interbank balances. Thirdly, the banking department operated like any commercial bank regarding its discount operations. In this respect, it set the discount rate - the Bank rate. The discount rate policy, set by the banking department, radically changed from those conducted by the Bank under the Old system, between 1821 and 1844. Such a break from the past deserves further examination.

Under the Old system, the Bank of England set a fixed rate of 4\%, which stood above the market rate in normal times. The purpose of the fixed rate policy was to maintain a large reserve of bullion in order to counter external drains in crisis times and to lend in last resort, at a moderate rate in order to counter internal drains. ${ }^{5}$ From September 1844 onwards, the banking department fulfilled a "new" discount policy. Henceforth the Bank rate significantly followed the market rate. The purpose was to reduce the opportunity cost related to the banking reserve holdings and to be

\footnotetext{
${ }^{5}$ The fixed rate policy was described or advocated by Palmer (PP, 1832, qs. 170-2, 171-172, 477), Tooke (1840, p. 189), Fullarton (1845, pp. 149-50), the Lords' Report (PP Lords 1848, pp. xxxiii-xxxiv), Tooke (1848, p. 383), Tooke (PP, Commons, 1848, qs. 5310-5313, 5348-5352), Tooke and Newmarch, (1857, p. 599), Mill (PP, 1857, qs. 2015, 2032, 2071), and Newmarch (PP, 1857, qs. 1359-1363, 1447, 1494, 1885).
} 
competitive within the discount market (King, 1936, pp. 111-2; Davutyan and Parke, 1995; Le Maux, 2018). The result of the new discount policy was that the Bank rate became unstable. Once the 1844 Act came into effect, the banking department lowered the Bank rate from $4 \%$ to $2.5 \%-$ this was an unprecedented cut, insofar as the Bank of England had never lowered its rate below $4 \%$ since its founding in 1694 . The $2.5 \%$ rate corresponded to the market rate prevailing in London over the previous two years. Afterwards, in the panic of 1847, the banking department raised the Bank rate to $8 \%$ for four weeks - an unprecedented rise that the Committee of the Lords deemed "exorbitant" (PP Lords 1848, q. 534). After the storm, the banking department continued its active and competitive rate policy. An unprecedented cut down to $2 \%$ took place in 1852 over a period of 37 weeks; later, the banking department again set its rate at 2\% in 1862 for 14 weeks' duration and in 1867 for 69 weeks' running. In the meantime, during the panics of 1857 and 1866, the Bank rate was set at $10 \%$, respectively, for six and twelve weeks - an unprecedented rise over an unprecedented length of time. ${ }^{6}$

The 1866 panic was the paroxysm of disruption of the Peel system. Externally, the Bank of England failed to attract significant metallic reserves despite raising its rate to $10 \%$, while the rate set by the Bank of France remained at 4\%. Newmarch (1866, pp. 230, 239) stressed that the very high Bank of England rate could send a warning signal to investors abroad that the domestic situation was hopeless and thereby make matters worse. Domestically, the banking reserve was as low as $£ 850,000$ in May, with the threat that the banking department could suspend its payments in Bank notes, while the metallic reserve at the issue department still remained at $£ 11.8$ million. Bagehot (1873, p. 64) considered that the Bank acted for "the best" in 1866. Nevertheless, Bagehot (1864b, pp. 431-3) glimpsed for a moment that "the effect of separation of the banking reserve from the currency reserve is to isolate the banking reserve - to expose it alone to an unfavourable change"; consequently, the Bank directors were "compelled in rational prudence to raise their rate"; then, it was concluded that the downward volatility of the banking reserve was the "great good of the Act of 1844" (in that it alarmed the Bank directors) and the "great evil of it" (in that it also alarmed other people). The ensuing paradox is that the Bank's management of the 1866 crisis is generally considered a key moment in the history of central banking in Britain, even though the Bank rate at $10 \%$ during three months rather revealed a failure.

To conclude, Bagehot took all the features of the Peel system for granted, and particularly the separation of the Bank of England through which the issue department followed the currency principle, while the banking department followed the discount market rate. It was in such historical and institutional contexts that Bagehot formulated the rule of the high Bank rate. So what could be

\footnotetext{
${ }^{6}$ Even though Bagehot (1873, p. 46) affirmed that "up to about the year 1860, the Bank of England did not perform at all" its "duty" to raise the interest rate "at the very beginning", the rise in the Bank rate to $8 \%$ and $10 \%$ had been prompt and high in 1847 and 1857. Bagehot (1873, p. 47) conceded that the panic of 1857 "for the first time taught the Bank directors wisdom, and converted them to sound principles"- namely, the setting of the Bank rate at $10 \%$ at the beginning of the crisis. Collins (1992), Bignon, Flandreau, Ugolini (2011), Flandreau and Ugolini (2013), Anson et al. (2017), Anson et al. (2019) have provided studies on the financial crises of 1847, 1857, and 1866.
} 
the function of the central bank in such system? How could a lender-of-last-resort theory emerge from within?

\section{The Bank policy and Bagehot's position}

Bagehot (1873, p. 329) proposed to "retain" the British banking system in his day and he only attempted "to mend and to palliate it." Bagehot's intention was to show how the lender-of-lastresort function could be compatible with the currency doctrine and the Peel system. But such a task stood apart from classical central banking (that is, both the classical central banking theory initiated by Henry Thornton and developed by Thomas Tooke, and the classical central banking policy of the Bank of England under the Old system), especially with respect to the holding of the banking reserve (2.1), the setting of the Bank rate (2.2), and the lending-of-last-resort framework (2.3). For the sake of clarity, we shall refer to the "metallic reserve" as the reserve in the form of bullion and specie held in particular by the issue department, and the "banking reserve" as the reserve in the form of Bank notes held by the banking department and other commercial banks.

\subsection{The banking reserve}

The Peel system was thought of as a decentralized system of the banking reserve (Peel, 1844; Hankey, 1867). Subsequently, Bagehot $(1848,1857,1866,1873)$ repeatedly regretted that the Bank of England system remained a "one-reserve system."7 But his choice of words was vague and confused. Literally, under the gold specie regime, this would mean that the Bank of England was the sole institution holding the metallic reserve. But such was not the case under the classical specie regime. Actually, specie circulated among the public and could be deposited with commercial banks; these banks then held an amount of specie reserve in their own vaults and deposited another amount with the central bank; finally, the latter centralized a large part of the metallic reserve. Commercial banks were legally compelled to reimburse their demand debts in specie and possibly in Bank notes and, ultimately, the Bank of England had to reimburse its demand debts in specie and bullion. All things considered, the central bank held in consequence a large share of the specie and bullion, but this does not mean that it held all the metallic reserves of the country. In other words, the centralization of the reserve (the fact that banks deposit a part of the metallic reserve with the central bank) is not identical with the one-reserve system (the fact that the central bank holds all the metallic reserve). Therefore, Bagehot criticized either a function of central banking under the specie regime (the centralization of the reserve in bullion and specie), or something that did not exist at his time (the one-reserve system). In Bagehot's mind, the

\footnotetext{
${ }^{7}$ In many passages, as previously seen, Bagehot (1857f, p. 377; 1864d, pp. 443-4; 1864e, p. 451; 1866b, p. 97; 1866e, pp. 18-9; 1867b, p. 23; 1873, pp. 67, 104, 106, 292,329; 1875,q. 8099) mounted a defense of the decentralized reserve system. In addition, Bagehot (1866f, p. 1106) considered that the one-reserve system, that is, "one bank keeping the sole banking reserve", was an "anomaly" and a "great evil"; and Bagehot (1873, p. 66), that "the system of entrusting all our reserve to a single board, like that of the Bank directors, is very anomalous." See also Bagehot (1857h, p. 381), Bagehot (1869b, p. 34), and Bagehot (1873, pp. 66, 70, 100, 108, 296, 297). See also Palgrave (1874, pp. 101-2).
} 
meaning of "one-reserve system" was, on the one hand, the process of centralizing a significant part of the metallic reserve at the Bank of England and, on the other hand, was opposed to the decentralization of the banking reserve that Bagehot incessantly advocated.

The expression "one-reserve system" was not only a poor choice of words, it also revealed theoretical weaknesses. Bagehot (1866d, p. 16) asked why commercial banks would have to deposit their metallic reserve with a clearinghouse or a central bank, and he claimed that it was "singular" that one bank should be engaged to keep "much unused, unprofitable, unearning money" for all other banks. There are at least three theoretical arguments that Bagehot did not consider. First, the participation of commercial banks in the system of multilateral clearings of demand debts helps them to speed up the return of notes and cheques issued by rival banks. Second, the holding of accounts at the clearinghouse or the central bank helps them to settle net clearing instead of using metallic reserves held in their vaults. Third, the multilateral clearing system helps the banking system at large to be economical in the use of metallic reserves and to speed up the circulation of specie. Finally - as Kindleberger (1980, p. 120; 1983, p. 81) and Laidler (1991, p. 184; 2000, p. 26) point out-Bagehot ignored economies of scale resulting from the centralization of reserve holding.

In addition, contrary to what Bagehot (1864d, p. 443; 1873, p. 100) hinted, the process of centralization is not necessarily the consequence of legal privileges. Fundamentally, it rests upon the relative efficiency of the multilateral clearing system which can operate under a mature free banking system as well as under the central banking system. In its first stage, the free banking system may be identical with the decentralized reserve system in which banks keep metallic reserves in their own vaults. But this is no longer the case in a mature free banking system in which banks deposit and keep their reserves at the clearinghouse which in turn centralizes a part of the metallic reserve (Selgin and White, 1994). The essential difference between the mature free banking system and the central banking system rests on the ability of the central bank to issue high-powered medium and thereby to act as lender of last resort (Le Maux, 2021). As a result, Bagehot's plea for the decentralization of the reserves may be seen as a crude regressive banking system, not only in comparison with the central banking system, but even in comparison with a mature free banking system. Such ignorance of the convenience of multilateral clearing and centralizing of metallic reserves at the central bank did not endear Bagehot to the proponents of classical central banking theory.

Prior to the publication of Lombard Street, classical monetary theory with Cantillon (1755), Smith (1776), Tooke (1844, 1848), Mill (1844, 1848), and Fullarton (1845) had developed theoretical arguments explaining the rationale of the clearing arrangements and the centralizing of metallic reserves. Later, Jevons (1875, pp. 322-4) emphasized that an institution setting up clearing arrangements economized on the metallic reserve and so countered Bagehot's defense of the decentralization of the reserve holding. Bagehot's mistake was not only related to the theoretical issue but also to the description of the monetary and banking institutions. For instance, Bagehot 
(1866g, p. 1418) claimed that, as a consequence of the National Banking Act of 1863 in the United States, "the system in which each leading bank keeps its own reserve-a system such as prevailed in New York - is safer, better, and more scientific." But, at the time, the New York Clearing House centralized a part of the lawful money deposited by the New York national banks. So it is difficult to see how the National Banking System could be "safer, better and more scientific" than the Bank of England system, nor why the Congress of the United States decided through the 1910 National Monetary Commission to create a central bank-a point that Laidler (1988, pp. 106-7) also underscores.

Now, I consider Bagehot's recommendation about the level of the banking reserve held by the banking department of the Bank of England. Although Bagehot clearly supported the decentralized reserve system, Bagehot (1857f, p. 377; 1857h, p. 384; 1858, p. 60; 1873, pp. 35-6, 55-6) proposed holding a large banking reserve. In fact, Bagehot's recommendation confirmed the view of the Bank directors under the Peel system. Among the Bank directors, Thomas Weguelin (PP, 1857, qs. 259, 282) estimated that a banking reserve equal to one-fourth of the deposits was sufficient as a minimum to uphold public confidence and specified that it could fluctuate between one-fourth and one-third (Bagehot, 1857f, p. 375; 1857h, p. 384; 1873, p. 186). Thomson Hankey (1867, pp. $19,26)$ suggested that one-third of the liabilities was a sufficient reserve ratio for the banking department at any time (Bagehot, 1873, p. 184). In Lombard Street's sinuous passages, Bagehot (1873, p. 187) first assessed that one-third of banking reserves backing the deposits of the banking department was "by no means an adequate reserve" and was "not even a proper minimum, far less a fair average." Then, Bagehot (1873,p. 318) came to the view that "no certain or fixed proportion" could be laid down and that the "old" one-third proportion must be "abandoned." Finally, Bagehot (1873, p. 333) proposed that "the banking department of the Bank of England should always keep a fixed proportion - say one-third of its liabilities - in reserve." These circumvolutions finally led to the same proportion that Hankey had suggested.

\subsection{The Bank rate}

The proponents of the 1844 Act asserted that the rule of issue was sufficient to protect the metallic reserve for the reason that it compelled the issue department to react at the right time and in the right amount. The interest rate set by the banking department was not envisioned as an alternative instrument for preserving the metallic reserve, but as the instrument for enhancing the competitiveness of its discount activity. As already seen, the policy of the banking department broke with the $4 \%$ rate policy, which yielded low revenue from discount activity in normal times and did not satisfy the Bank's shareholders, as the director James Morris testified (PP Commons 1848, q. 2641). Bagehot (1861, pp. 20-1) referred to the Bank rate policy under the Old system (that is, the fixed rate policy à la Thomas Tooke), through which "the Bank should fix on some arbitrary rate" and "hold resolutely aloof-discount no bills and seek to discount no bills - but augment its reserve as much as it can"; and he was aware that, according to the "opposite school" 
(that is, the active rate policy à la Robert Peel), the Bank "should look to itself" and "consider only its proprietors and be watchful only about its dividends."

Bagehot (1873, p. 115) then criticized the fixed rate policy arguing that "the notion that the Bank of England has control over the money market, and can fix the rate of discounts as it likes, has survived from the old days before 1844, when the Bank could issue as many notes as it liked" (italics added). Nonetheless, such a claim is neither fair nor relevant for at least three reasons. First, under the Old system, the Bank did not attempt to "control" the money market but contributed to stabilizing the market discount rate through the fixed rate policy. Second, the Bank could not issue "as many notes as it liked" as long as they were convertible into specie, which had always been the case between 1821 and 1844. Finally, one cannot see how the Bank could over-issue so long as its rate was for most of the time above the market rate. In fact, it was exactly the reserve-and this is what Bagehot (1861, pp. 20-1) implicitly recognized inasmuch as its rate was not competitive, the Bank did not discount as much commercial paper as it liked. The Bank's shareholders indeed deplored such a situation and called for a new discount policy (Morris, PP Commons 1848, q. 2641; Cotton, PP Lords 1848, q. 3214). Therefore, under the Peel system, the Bank rate tracked the market rate with the result that the banking department could be competitive in the discount market and increased its revenues from discount activities.

In Lombard Street, Bagehot kept in mind the concern for profitability demanded by the Bank's shareholders and described how the new discount policy impacted the management of the banking reserve: the Bank's proprietors "always urge their directors to diminish (as far as possible) the unproductive reserve, and to augment as far as possible their own dividend", that is, "to keep a small reserve, whereas the public interest imperatively requires that they shall keep a large one" (Bagehot, 1873, pp. 39, 109, 160-1). The new discount policy also impacted upon the setting of the Bank rate: "As soon as the Bank rate is fixed" and remains above the market rate, "a great many persons who have bills to discount try how much cheaper than the Bank they can get these bills discounted"; when the Bank "sees that its business is much diminishing, it lowers the rate, so as to secure a reasonable portion of the business to itself" (Bagehot, 1873, pp. 114-5). Finally, Bagehot (1873, p. 38) described the technique of benchmarking (which attempted to reduce the discrepancy between the profitability of Bank of England stocks and, say, those of the London and Westminster Bank): “That the Bank proprietors should not like to see other companies getting richer than their company is only natural" (italics added; also Bagehot, 1866d, p. 16; 1873, p. 161). In this respect, Bagehot (1873, p. 195) acknowledged that the banking department under the Peel system had "no great prestige" (original italics) - when Newmarch (PP, 1857, q. 1364) attributed "a moral prestige" to the Bank of England under the Old system. Nonetheless, Bagehot did not call into question the new discount policy - and even disapproved of the fixed Bank rate policy.

The flip side of the competitive discount policy was that the banking department of the Bank of England suddenly increased its rate under strained conditions. As early as the crisis of 1847 , the 
Bank directors discovered that the rule of issue did not suffice. They had to use the Bank rate to counter bullion outflows and thence forged in practice the policy through which the interest rate became the instrument of protection of the metallic reserve during commercial crises (Morris, PP Commons 1848, qs. 2647, 2816, 2840). Bagehot (1866c, p. 101) himself recognized that the violent rise in the Bank rate was the artifact of the 1844 Act, which "compels the Bank to act at an early stage during a foreign drain of bullion. [The Bank] must with the Act [of 1844] raise the rate of discount; [the Bank] ought not to raise it without the Act" (original italics). Nonetheless, Bagehot did not draw any conclusion and did not call into question the Peel system.

Bagehot took the new discount policy for granted, whereby the Bank rate tracked the market rate, and he specified that the Bank rate setting was to be asymmetrical. Regarding the downward change in the Bank rate, Bagehot (1861, pp. 21-2) argued that "the duty of the Bank directors in a time of ease and quiet is to move with the market, or after the market. [...] They should not remain immovable far above the market rate" (original italics). By contrast, concerning the upward change in the Bank rate, Bagehot (1873,pp. 319,320) considered "erroneous" the rule by which "the Bank of England should look to the market rate, and make its own rate conform to that." Thus, the Bank rate should not be only "high" like the market rate but "very high" relative to the market ratemeaning that the banking department should set its rate above the market rate in crisis times. In this respect, Bagehot did not only follow the Peel system but even went beyond it.

\subsection{Lending of last resort}

The framework of the 1844 Act left no scope for action by the Bank of England as lender of last resort. The issue department could not put into circulation more notes than the metallic reserve at the margin and no suspension clause was envisaged. The banking department was designed as a commercial bank like any other and as a lender among others in the money market. Notwithstanding, the Bank was compelled to intervene from the 1847 crisis onward. Hence, the Peel system determined the forms of the Bank's intervention and also framed Bagehot's analysis. So, in order to analyze the working of the lender of last resort $a ̀$ la Walter Bagehot, it is important to understand how the separation of the Bank into two departments involved two forms of intervention.

The first form concerned the issue department and was possible through the suspension of the statutory rule of issue of Bank notes as was the case in 1847, 1857, and 1866. In turn, two interpretations of the suspension of the 1844 Act are possible. One interpretation is that the issue department could issue more Bank notes than the statutory rule would permit - that is, the issue department's liabilities increased and the amount of its metallic level remained the same. Another interpretation is that the suspension of the statutory rule gave the banking department access to specie held in the issue department — that is, the issue department's liabilities remained the same, but the amount of its metallic reserve fell. In any case, the Bank put extra notes into circulation and thereby transferred liquidity to the banking department which then allocated liquidity to the 
money market. Bagehot (1848, p. 267; 1857f, p. 370; 1866b, p. 95) did mention the three occurrences (in 1847, 1857, and 1866) of the suspension of the statutory rule of Bank note issue. The suspension of the 1844 Act (the suspension of the "currency principle") by no means corresponded to the suspension of convertibility into gold specie (the suspension of the "gold standard"): the Bank of England was authorized to suspend the statutory rule of issue and at the same time maintained the convertibility of its notes on demand into specie at face value.

The second form of intervention of the Bank of England concerned the banking department and its activities of discount or purchase of bills and securities (irrespective of the suspension of the rule of issue of Bank notes). In turn, two modes were possible. One mode was the transfer of a part of the reserve in Bank notes to commercial banks against bills and securities - that is, the structure of the banking department's assets changed. Here, the mode of transfer set the banking department on the same footing as any other bank. The other mode for the banking department was the issue of high-powered medium in the form of banker's deposits - that is, the banking department's liabilities increased. There, the mode of issue set the Bank above other banks because the Bank was the sole institution able to issue high-powered medium unequivocally accepted among the other banks. Bagehot rarely referred to the mode of issue but mostly instead to the mode of transfer (Bagehot, 1873, pp. 46-8, 51, 55-6, 64, 173, 196). Such a choice of mode of intervention finally impoverished the analysis of central bank policy. (By contrast, it may be emphasized, Thomas Tooke and the Bank directors under the Old system referred mainly to the mode of issue irrespective of the form of Bank liabilities, Bank notes or commercial banks' deposits with the Bank).

Peel (1844, p. 75) saw no inconvenience in the 1844 Act leading to "diminish the power of the Bank to act with energy at the period of monetary crisis and commercial alarm and derangement"- meaning that before the 1844 Act the Bank could a contrario intervene "with energy" during financial crises. It was believed that the 1844 Act would help to end the need for lending in last resort; that no bank would structurally overtop the others; and finally that any participant in the money market would lend liquidity in times of pressure. Thus, Peel (1844, p. 75) argued that in such altered periods " all who are possessed of unemployed capital, whether bankers or not, and who can gain an adequate return by the advance of capital, are enabled to afford, and do afford, that aid which it is supposed by some that banks alone are enabled to afford" (italics added). Bagehot (1866e, p. 19) restated Peel's idea as follows: in a decentralized banking system or, "in a natural system, if we may so call it, no one bank would in time of extremity be charged by custom or habit with the duty of lending to all other banks. Each would take its chance, and no one would have a particular claim on any other." Even if Bagehot (1873, p. 69) did "not suggest" to "return to a natural or many-reserve system of banking", his analysis was however haunted by the decentralized organization of the banking reserve that he advocated. In other words, he reasoned as if banks (the banking department as well as the commercial banks) were holding their own banking reserves (the Bank notes) they could possibly lend. 
It follows that the Bank as well as the banks should implement the same rule of conduct for the transfer of banking reserves during panics. The fact that Bagehot's recommendations apply to the Bank as well as the banks is commonly neglected in the literature so that it is worth quoting several excerpts in full (all italics are added). Bagehot (1873, pp. 48, 173) explicitly applied the rule of lending freely on good securities to all kinds of banking institutions: "the best way for the bank or banks who have the custody of the bank reserve to deal with a drain arising from internal discredit, is to lend freely" and "the holders of the ultimate Bank reserve (whether one bank or many) should lend to all that bring good securities quickly, freely, and readily." So, the Bank "must in time of panics do what all other similar banks must do", that is, to "advance freely and vigorously to the public out of the reserve" (Bagehot, 1873, p. 196). The characteristic of the Bank, Bagehot (1873, p. 64) observed, was simply that its banking department held a large part of the reserve in Bank notes: "whatever bank or banks keep the ultimate banking reserve of the country must lend that reserve most freely in time of apprehension [...]. Whether rightly or wrongly, at present and in fact the Bank of England keeps our ultimate bank reserve, and therefore it must use it in this manner." Bagehot (PP, 1875, qs. 8113, 8170) repeated that "the banking reserve, whether it is held by many banks or by one" should be lent out "freely" and on "good security." Finally, Bagehot (1873, p. 46) similarly applied the rule of lending at a very high rate to all kinds of banking institutions: "whatever persons-one bank or many banks - in any country hold the banking reserve of that country, ought at the very beginning of an unfavorable foreign exchange at once to raise the rate of interest." Thus, Bagehot's rule did not so much apply for the central bank as for all bankers participating in the money market.

All the above-quoted passages from Bagehot are fully in line with the spirit of the separation of the Bank (Peel, 1844,pp. 36-8) and with the declaration of Bank directors (Prescott, PP Commons 1848, q. 2653). Under the Peel system, the Bank and the banks were placed on the same footing. All could possibly transfer a part of the banking reserve they held, and the difference between them was of degree, not of kind. The rules of conduct did not strictly apply to the central bank but all banking institutions participating in the money market. As a matter of fact, as Tooke and Newmarch (1857, p. 544) deplored, there was henceforth no bank "wholly distinct" from other banks. ${ }^{8}$ By contrast, under the Old system, the Bank of England was clearly distinct from the other commercial banks: the sole reserve was the reserve of bullion for all purposes; the Bank rate was fixed at $4 \%$ and did not rise above $6 \%$ during financial crises, and the Bank director did not attempt to follow the market rate; the mode of intervention as lender of last resort mainly rested on the issue of high-powered media and large facilities through the discounting of bills and outright purchasing of securities.

\footnotetext{
${ }^{8}$ In his Art of Central Banking, Hawtrey (1932, pp. 67-8) implicitly shared Tooke and Newmarch's view and rightly pointed out that Bagehot's view "understates the Bank's power. It is not merely that the Bank 'used to be a predominant, and is still a most important, dealer in money' [Bagehot, 1873, p. 114]. The Bank of England is the bankers' bank, and in that capacity the lender of last resort. [...] Its notes and deposits form the cash reserves of the other banks, and it can, by regulating the amount of its own advances, discounts and investments, modify the amount of these cash reserves at its discretion."
} 
Our reading of the Economist's editorial articles and Lombard Street does not strictly find several interpretations often attributed to Bagehot. The first adage associated to Bagehot is that the central bank should lend to temporarily illiquid but not to insolvent banks. More precisely, Bagehot's (1873, p. 198) concern dealt rather with the quality of the pledged collateral: "the bank, or banks, holding the ultimate reserve should refuse bad bills or bad securities [...] The 'unsound' people are a feeble minority [...] The great majority [to be protected] are 'sound' people, the people who have good security to offer" (italics added). The second interpretation is that the central bank should lend to the market through open-market operations (Goodfriend and King, 1988; Bordo, 1990; Kaufman, 1991; Wood, 2000; Capie, 2007). In fact, Bagehot (1873, p. 51) stated that the "the holders of the cash reserve" should "lend to merchants, to minor bankers, to "this man and that man" (italics added). So, as Keleher (1999, p. 3) suggests, the central bank rather lends to institutions through the discount window. Furthermore, it is difficult to see how, in Bagehot's design, the banking department, the banks, the holders of the reserve could "lend to the market" inasmuch as they all stood within the market. The third interpretation is that the central bank should accept customary securities at pre-crisis values (Garcia and Plautz, 1988, p. 26; Santos, 2006, p. 465). Rather, as Humphrey (1975, p. 7) comments, the lender of last resort should accept securities considered good in normal times and "extend loans on assets whose current market value is temporarily below book value." Lastly, as will be discussed in section 3.2, Bagehot did not suggest a "penalty" rate (a term he did not use) so as to counter moral hazard, but a "very high" rate in order to force banks to exhaust market sources of liquidity before presenting at the discount window.

To conclude, the Peel system that Bagehot took for granted was a dismantled construction in that there were two modes of intervention depending on the respective department and the form of issue-namely, the Bank notes from the issue department and the banker's balances from the banking department. During financial crises, the banking department suffered from a sharp fall in its reserve of Bank notes while, to add irony to difficulty, the issue department was full of reserve of bullion. Confusion was then possible in Britain and abroad. Money market participants were directly or indirectly in contact with the desk of the banking department and tended to associate the banking department with "the Bank". So when the banking reserve declined drastically, it was believed that "the Bank" was close to suspending "its payment", whereas the Bank held a comfortable reserve of gold coins and bullion. The very high interest rate was a consequence and even an adjustment of the unsteady construction owing to the separation of the Bank into two departments. By analogy with mechanics, a cantilevered piece created the need for a supplementary force that prevents the element subjected to contrary forces from breaking. All the same, Bagehot (1873) did not call for the repeal of the Peel system and simply considered the very high interest rate as the "right" principle. 


\section{Bagehot's rule - what (a) rule ?(!)}

As Baring (1797) had done previously, Bagehot (1857f, p. 374) used the French expression dernier ressort associated with the lending power of the Bank of England. Various testimonies to the 1832 parliamentary inquiry show that an expression such as 'lending liberally on secure collateral' was a commonplace description of the action of the Bank from the crisis of 1825 onward. The theoretical question then concerned the setting of the interest rate and whether the central bank could or should lend at a moderate or a high interest rate. After the presentation of Bagehot's proposition by which the central bank should set a "high" and even a "very high" interest rate (3.1), the different contemporary interpretations of Bagehot's rule will be surveyed especially regarding the interbank concern (3.2), and Bagehot's rule will finally be discussed in the light of the classical central banking theory especially with regard to international concern (3.3). We shall refer to "Bagehot's rule" as the setting of the interest rate at a very high level for all purposesmeaning that the rate must be (i) higher than those set in normal times, (ii) higher than the market rate, and (iii) higher at the beginning of the crisis - in contrast with "Tooke's rule" of moderate rate.

\subsection{Lending of last resort and Bagehot}

Long before Lombard Street, central bankers formulated the "lending liberally" rule under the Old system. In his testimonies to the 1832 parliamentary inquiry, the Bank director Palmer (PP 1832, q. 177) gave an exhaustive definition of lending of last resort: "In a time of discredit, it is extremely desirable that the Bank should grant the requisite aid to the public, by an increased issue of their notes; and there are times when the Bank may afford considerable facilities to the commercial interests through discounts, by changing a part of their Exchequer Bills into securities of the former character" (see also Jeremiah Harman, PP 1832, q. 2217). It may be noted that Bank directors' testimonies here described both the issue of high-powered money in large amounts (lending in last resort) and also the swap between questionable private sector and public sector securities (market making in last resort). Among bankers in London, it was perceived that, during the financial collapse in December 1825, "the Bank of England discounted all the bills sent in as liberally as possible" (Nathan M. Rothschild, PP 1832, q. 4895).

The "lending on secure collateral" rule was also the concern of the Bank directors about the range of acceptable securities. Palmer (PP, 1832, q. 164) explained that during the 1825 crisis "every sort of security was tendered to the Bank at that period, upon which advances were made without much inquiry as to their nature, provided they were deemed to be eventually secure." Later, the director Morris (PP Lords 1848, q. 536) declared that, during the crisis of 1847, the Bank "has not refused to discount any bills, provided the rate of interest [at 8 per cent] which we proposed was such as the party would give, and we thought security good." Other evidence shows that the range of accepted collateral was quite large: the resolution of the Bank directors in October 1847 stated 
"That the minimum rate of discount on bills not having more than ninety-days to run be 8 per cent; That advances be made on bills of exchange, on stock, Exchequer bills, and other approved bills" (quoted in Palgrave, 1910, p. 205).

In this respect, Bagehot (1873, pp. 51, 198, 205, 320) provided interesting insight into the ranges of the counterparties and collateral securities. He envisioned that these ranges should be wide enough to mitigate pressure in the money market and so recommended that the Bank of England should lend to merchants and discount houses, as well as bankers and against every kind of current securities. Bagehot (1873, p. 197) explained that "if it is known that the Bank of England is freely advancing on what in ordinary times is reckoned a good security - on what is then commonly pledged and easily convertible - the alarm of the solvent merchants and bankers will be stayed." This leads to the view that, in a banking panic, the Bank is the "the sole lender" (Bagehot, 1873, p. 205) and even the sole securities buyer: "The Bank of England could not sell 'securities,' for in an extreme panic there is no one else to buy securities" (ibid, p. 66). Interestingly, it is then concluded that: "No one knows on what kind of securities the Bank of England will at such periods make the advances which it is necessary to make" (ibid, p. 204). It may be noted, however, that all these excerpts move away from Bagehot's leitmotiv that the Bank as well as banks could advance banking reserves. By pointing out that the Bank was the sole market participant to accept a wide set of collateral securities in a panic, by stating in consequence that the ranges of counterparties and collateral securities were or should be large enough, Bagehot implicitly envisioned the central bank as the market maker of last resort. ${ }^{9}$

Finally, the "very high rate" rule was rather particular to Bagehot even though officials shared it when Lombard Street was being published. In 1873, indeed, the Chancellor of the Exchequer Robert Lowe presented to Parliament "A bill to provide for authorising in certain contingencies a temporary increase of the amount of Bank of England notes issued in exchange for securities" with the following rule: "That the minimum rate of interest then being charged by the Governor and Company of the Bank of England on discounts and temporary advances is not less than twelve per cent per annum" (original italics, quoted in Palgrave, 1910, pp. 178-9). As seen in section 2.2, the rule of high and even very high rates was institutionally related to the Peel system - and not simply to the specie regime-from the 1847 crisis. As will be seen in section 3.2, one of Bagehot's arguments is related to the domestic interbank market irrespective of the monetary regime: the Bank rate should be "very high" in that it should be higher than the market rate. And, as will be seen in section 3.3, another of Bagehot's arguments is related to the metallic regime. It rests on the lack of distinction between real factors and financial factors referring to the drains of bullion: the

\footnotetext{
${ }_{9}^{9}$ Humphrey and Keleher (1984, p. 302), Meltzer (1986, p. 82), Moore (1999, p. 453), and Repullo (2000, pp. 580-1) provide an interesting interpretation of the above-quoted passages from Bagehot. The concept of "market maker" or "dealer" of last resort has been forged by Buiter and Sibert (2007) and Mehrling (2011), and it makes sense since the credit system is based significantly on the securities markets - as was the case in Britain during the nineteenth century. Furthermore, Mehrling, Pozsar, Sweeney and Neilson (2014) accurately show that the shadow banking system in today's world bears resemblance to the discount system in Bagehot's day.
} 
Bank rate should be "very high", not only because it should be higher than the market rate, but also because it should be increased from the beginning of the crisis.

\subsection{The interbank level: interpretations and discussions}

At the interbank level, the purpose of the penalty rate (even if Bagehot did not use the word "penalty rate" but the word "fine" or "very high rate") is subject to two different interpretations.

A first interpretation states that it addresses liquidity retention and prevents any calls for liquidity immediately at the discount window - let us call this the "retaining" interpretation. ${ }^{10}$ Indeed, the following passage from Bagehot (1873, p. 197) validates the retaining interpretation: the Bank should increase its rate to a "very high rate" which operates "as a heavy fine on unreasonable timidity, and will prevent the greatest number of applications by persons who do not require it. The rate should be raised early in the panic, so [...] that no one may borrow out of idle precaution without paying well for it." The aim is not to sanction ex ante rashness but ex post timidity from banks, whose needs are not urgent and which are prone to rush, in the first resort, on the central bank. It gives incentives for banks to exhaust all market sources of funding before asking for central bank liquidity, and thereby, to encourage the revival of the interbank market. Thus, it is expected that only a few banks would have to ask for liquidity at the central bank's desk.

A second interpretation states that the rule of a very high rate addresses moral hazard and prevents banks from risk-taking - let us call it the "moral-hazard" interpretation. ${ }^{11}$ However, Bagehot (1873, p. 104) mentioned moral hazard in passing and did not associate it with his very high rate rule - while the classical tradition of central banking, with Thornton (1802, p. 188) and Fullarton (1845, pp. 163, 210) had previously recommended banking supervision to address the moral hazard problem. The fact that Bagehot $(1873$, pp. 35, 73, 173, 198, 206) suggested that the availability of lending in last resort should be pre-announced might explain why the moral-hazard interpretation has been widespread. If banks are sure to benefit from the support of the central bank, it is argued, they are led to take more risks than they would otherwise have chosen to do. So a pre-announced penalty rate would be required. On the other hand, the moral-hazard problem and the penalty-rate solution have often been discussed. First, the penalty rate set by the central bank exacerbates liquidity pressure within the interbank market and intensifies coordination failure

\footnotetext{
${ }^{10}$ Bradford (1874, p. 349), Humphrey (1975, p. 7), Humphrey and Keleher (1984, pp. 301-2), Meltzer (1986, p. 83), Humphrey (1989, p. 14), Kindleberger (1996, p. 123), Fisher (1999, p. 90), Giannini (1999, p. 12), Keleher (1999, p. 3), Moore (1999, p. 452), Acharya and Backus (2009, p. 307), Martin (2009, p. 399), Bernanke (2008), Madigan (2009), Bignon, Flandreau and Ugolini (2012), suggest the retaining interpretation. Hirsch (1977) criticizes Bagehot for ignoring the moral hazard problem.

${ }^{11}$ Solow (1982 [2002], p. 240), Guttentag and Herring (1983, p. 17), Claassen (1985, p. 222), Garcia and Plautz (1988, pp. 24-7), Crockett (1997, p. 25), Fisher (1999, p. 90), Freixas, Giannini, Hoggarth and Soussa (2000, p. 74), O'Brien (2003, p. 11), Buiter (2008, p. 514), Castiglionesi and Wagner (2012, p. 202), Domanski, Moessner and Nelson (2014, pp. 44, 47), Hogan, Le and Salter (2015, p. 337) expound the moral-hazard interpretation.
} 
during panics (Freixas, Martin and Skeie, 2011). Second, since the distinction between illiquidity and insolvency is made, the penalty rate may be counterproductive and worsen the ex-ante moral hazard that it was supposed to prevent (Castiglionesi and Wagner, 2012). Third, it can be added that, if a single penalty rate applied to all banks indiscriminately, it would create an adverse selection problem and might induce borrowers to choose risky projects. A solvent bank thus faces a dilemma: borrowing from the central bank at a very high rate will reduce its net worth, but not borrowing will endanger its liquidity.

However, one cannot blame Bagehot for an argument that he did not state (the moral-hazard argument). Even so, his argument (the retaining argument) remains open to discussion. The first rebuttal is that it implicitly rests on the assumption that the interbank markets are functioning well and that banking institutions are able to allocate liquidity efficiently among them in panics. However, the interbank market can be frozen: banks with a surplus are reluctant to grant credit to banks with a deficit against securities easily traded in normal times and thus leave liquidity idle. The coordination problem is aggravated by the very high rate set by the central bank: it pushes up the market rate, lowers prices in the securities markets, and finally depresses funding and market liquidity. ${ }^{12}$ In contrast, the classical central banking theory stressed that the Bank rate setting influenced the solvency of banking institutions (Tooke, 1844, p. 124). The contemporary literature develops further the coordination problem triggered by a very high rate setting (Guttentag and Herring, 1983; Crockett, 1997; Freixas, Parigi and Rochet, 2004).

The second rebuttal of the retaining argument may be found in the assumption that money market participants tend to regard the central rate as a reference. Since the central bank sets its rate at a higher level than the market rate, they will interpret such a signal as being the result of the growing crisis. As the market rate increases further, the central bank is compelled to raise its rate again in order to maintain the level above the market rate, and so on. Such an escalation heightens the interest rate instability and finally makes the retaining argument unsuitable. ${ }^{13}$ In contrast, the rule of the moderate rate appears more stabilizing. In classical central banking theory, it is considered that, once the central bank rate used as a reference stands below the market rate, the market participants are less prone to augment the market rate (Tooke, PP Commons 1848, qs. 5361-5366; Palmer, PP 1848 Commons, q. 1945; Tooke and Newmarch, 1857, pp. 544-5). In contemporary literature, Freeman (1996), Allen and Gale (1998), Antinolfi, Huybens and Keister (2001), Rochet and Vives (2004), and Martin (2006) go as far as to support a policy of a very low if not a zero

\footnotetext{
${ }^{12}$ Bagehot (1873, p. 189) glimpsed the problem of the money market freeze and stated that "in a panic there is no new money to be had; everybody who has it clings to it, and will not part with it." But this statement is in contradiction with the retaining argument which supposes that banks with a surplus could supply liquidity in the market before banks with a deficit are compelled to appear at the central bank's discount window.

${ }^{13}$ As already seen, Bagehot (1873, p. 66) envisioned the concept of the market maker in last resort, but the rule of a very high rate conflicts with the role of the market maker in last resort. Indeed, the very high rate worsens - when the purpose of the market making in last resort is to mitigate - the decline in securities prices.
} 
interest rate. However, under the specie regime prevailing during the classical period, the very low rate policy was not possible - at best the moderate rate policy was conceivable.

Lastly, Martin (2009) provides an interesting justification for the retaining argument and the ensuing high rate rule. Since there is enough banking reserve at the central bank to make loans to banks in deficit, banks have no reason to borrow the banking reserve unless they need it. In the event of a panic, banks may worry about the ability of the central bank (the banking department of the Bank of England under the Peel system) to provide enough banking reserves. Strategic interactions between banks then take place and they have incentives to insure themselves by borrowing banking reserves before they get into trouble. Hence, a high rate must be charged in order to prevent banks from asking for banking reserves before they need them. Otherwise, "when the central bank charges a low interest rate for its reserve, banks have an incentive to borrow before they know if they need the reserves. If the central bank charges a high interest rate, this incentive disappears" (Martin, 2009, p. 405). Such an interpretation of the retaining argument is particularly relevant under the mode of transfer of interbank liquidity (that is, under the Peel system and Bagehot's design) through which the banking department lends a limited holding of banking reserve. This is no longer the case under the mode of $i$ ssue of interbank liquidity (that is, under the Old system and Tooke's design) through which the central bank issues high-powered medium despite the constraint on convertibility into specie. As a reminder, under the classical specie regime, the Bank of England significantly increased the volume of high-powered medium during financial crises without suspending its payment in specie. Inasmuch as the central bank does not lend the banking reserve but elastically issues high-powered medium, the coordination problem arising within the Bagehot's design vanishes. Once banks know that the central bank can elastically provide liquidity through the issue of high-powered money (and not rigidly through the transfer of banking reserves), they are less prone to ask for liquidity before knowing whether they need it. Therefore, the raison d'être of the very high rate disappears and the central bank can maintain a moderate rate in accordance with Tooke's rule.

\subsection{The international level: "A uniform remedy for many diseases"}

With respect to the international level, the present-day literature considers that a sharp rise in the interest rate relies on the monetary regime prevailing in Bagehot's time in Britain, namely, the gold specie regime. The interest rate was the instrument through which the Bank of England maintained or attracted bullion from abroad. But such an interpretation does not explain why in Bagehot's time the Bank set its rate at a very high level. Historically, the Bank rate increased only up to $5 \%$ and $6 \%$ under the Old system, while it reached $8 \%$ and $10 \%$ under the Peel system. Institutionally, the Old as well as the Peel system fitted into the same gold specie regime. The inference is that the specie regime explains the rise in the interest rate, while the Peel system explains the high level of the rise. Theoretically, Bagehot's assumption that one instrument (the interest rate) should be used for two purposes (external and internal drains) determines the 
recommendation that the Bank should raise its rate not only to a very high level but also very early. So the lack of differentiation of drain factors (3.3.1) led to Bagehot's rule (3.3.2), whereas a precise distinction of drain factors is decisive for Tooke's policy (3.3.3).

\subsubsection{Diseases and factors of drains}

Classical central banking theory distinguished between two kinds of drain (internal and external drains) and also identified three causes of drains (monetary, real, and financial causes). In the context of the suspension of convertibility into specie in 1797, Thornton (1802) distinguished between monetary and real causes and considered that the external drain was temporary, if due to real factors only, but was unending if due to continuing monetary shocks. Within the context of convertibility into specie from 1821 onwards, Tooke (1844, 1848, PP Commons 1848, PP Lords 1848), Mill (1844, 1848), and Fullarton (1845) showed that the monetary factors were no longer relevant and that internal and external drains were due mainly to real factors and/or to financial factors (Le Maux, 2020).

Although Bagehot (1873, p. 43) recognized the two kinds of unexpected demand for metallic reserve (internal and external drains), he did not exactly identify the three factors (monetary, real, and financial factors). Concerning monetary causes of drains, Bagehot (1873, p. 116-8) restated the price-specie-flow mechanism according to which convertible bank issues could possibly be in excess and engender a rise in monetary prices, and then a drain of the metallic reserve. The preliminary instrument supported by the quantity theory, in order to counter price-specie flows, was the currency principle adopted by the 1844 Act (Torrens, 1844, pp. 35-6). Bagehot (1864f, p. 457) felt that the theory of the 1844 Act "had no reference to [...] the rate of interest." So Bagehot (1864g, p. 468) only departed from it in favoring the Bank rate as an instrument: "The theorists of 1844 perceived that a contraction of the credit currency was necessary, but, misled by natural circumstances, they mistook the mode of contracting it"; if the "great truth" of the 1844 Act was the necessity of contraction, the "mistake" was simply the instrument.

Regarding other (than monetary) causes of drains, all we can find in Lombard Street are different causes presented in disorder: "sudden trade of import, like the import of foreign corn after a bad harvest", "large and unusual foreign debts", "sudden apprehension and panic", and also "accidental events", which "are of the most various nature: a bad harvest, an apprehension of foreign invasion, the sudden failure of a great firm which everybody trusted." ${ }^{14}$ All these events look like various exogenous shocks. In addition, they are not categorized. Some of them correspond to real factors (productivity shock) and others to financial factors (adverse information on institutions, financial

\footnotetext{
${ }^{14}$ Bagehot (1873, pp. 43, 122). Previously, Bagehot (1858, p. 50) also mentioned in disorder: the "errors of the Bank directors, the railway mania, the bad harvest." Bagehot (1866b, p. 94) alluded to "the diffused though slight discredit", which is "caused by the known bad finance speculations", without defining and analyzing "speculation" or "bad" speculation.
} 
speculation). Some of them correspond to internal drains (exogenous banking panics) and others to external drains (importing of foreign goods). And the analysis of all these causes remains obscure in Bagehot's writing.

Concerning the internal drains, Bagehot (1866a, p. 88) defined a "panic" as "a general destruction of all confidence, a universal distrust, a cessation of credit in general." Then, Bagehot (1873, p. 51) just claimed that "a panic, in a word, is a species of neuralgia, and according to the rules of science you must not starve it." Bagehot (PP, 1875, q. 8007) also observed that a panic was an "unreasonable" thing. Nowhere did Bagehot propose a well-argued analysis of financial disruption. At worst, financial disruption is simply exogenous. At best, financial contagion is defined as a domino effect: "In the wild periods of alarm, one failure makes many, and the best way to prevent the derivative failures is to arrest the primary failure which causes them" (Bagehot, 1873, p. 51). Such a definition of the domino effect ensuing from outright default disregards the dynamic effect of asset price fall and liquidity shortage. ${ }^{15}$ Thereby, Bagehot (1873, p. 101) was led to the optimistic view that "the best thing undeniably that a government can do with the money market is to let it take care of itself." Here Bagehot once again echoed Hankey $(1867$, p. 21$)$, who did not "advocate for any legislative enactments to try and make the trading community more prudent" and would have been "sorry to see any interference to prevent persons overtrading or speculating." Such visions could not grasp how the competitive Bank rate policy could fuel speculation and, conversely, how a huge and hasty rise in the Bank rate could worsen distrust in the money market.

Regarding the external drains, irrespective of their causes, the interest rate was conceived as the main instrument for attracting capital and bullion from abroad. Bagehot (1864g, p. 467) argued that the "best method - the sole method - to contract the entire credit currency [...] is to raise the rate of interest" and that "by the prolonged action of 8 and 9 per cent, business is checked, prices fall, the exchanges are righted, the balance of trade redressed." Bagehot $(1873$, p. 46) further described two channels through which the rise in interest rate produces inflows of the metallic reserve from abroad: in the short run, the channel of the capital market is such that "loanable capital, like every other commodity, comes where there is most to be made of it." In the long run, the channel of the commodity market corresponds to a "slower" operation: after a rise in the rate of discount, "prices fall; in consequence imports are diminished, exports are increased, and, therefore, there is more likelihood of a balance in bullion coming" into the country.

A common interpretation considers that lending freely (as a protection against the internal drain) and the high interest rate (as a tool to counter the external drain) are complementary. ${ }^{16}$ The problem

\footnotetext{
${ }^{15}$ On the financial contagion, see also Bagehot (1873, pp. 53-4, 264-5) and Bagehot (PP, 1875, q. 8007). Thornton (1802, p. 180) was the first to mention the domino effect. All in all, as Laidler (2004b, p. 4) points out, Bagehot "lacked a coherent theory of what we would now call the business cycle", or the financial cycle.

${ }^{16}$ In this line, see Mints (1945, p. 191), Laidler (1988, p. 103), Humphrey and Keleher (1984, p. 299), Meltzer (1986, p. 81), Bordo (1990, p. 20), Kaufman (1991, p. 96), and Martin (2009, p. 399). Rockoff (1986, pp. 160-1) expounds a skeptical view of such complementarity.
} 
is that, as seen above, the high rate worsens interbank coordination and solvency of banking institutions. From the inside, the run to liquidity is more intense and, from abroad, the investors worry about the deterioration of the financial situation, which amplifies the external drain of bullion. As a result, the high interest rate may conflict with the attempt to stop the external drain. More generally, the lack of classification of causes of drain and Bagehot's ensuing rule lead to a deadlock. Bagehot (1866a, p. 91) himself recognized that, while the rise in the interest rate was supposed to "cure the foreign drain," such an increase "would not mitigate or diminish a domestic panic. Probably it might enhance the alarm." In contrast, as will be seen below, Tooke drew a distinction between real and financial factors and did not recommend the same treatment for each kind of drain: storing previously a large metallic reserve, and keeping the Bank rate fixed when dealing with real factors; keeping previously a large reserve, and increasing the Bank rate latterly and moderately when dealing with financial factors.

\subsubsection{Bagehot's three assertions}

In order to go over the examples of drains that Bagehot gave in disorder, three of Bagehot's assertions linked one to another may be discerned: (1) the absence of distinction between the causes of drain; (2) the absence of distinction concerning the remedy; (3) the absence of distinction concerning the sequence of the remedy. These three assertions will then be benchmarked with three of Tooke's propositions.

First, Bagehot (1873, pp. 122-3) asserted without any theoretical demonstration that no classification of drains is needed: "some writers have endeavoured to classify panics according to the nature of the particular accidents producing them. But little, however, is, I believe, to be gained by such classifications. There is little difference in the effect of one accident and another upon our credit system. We must be prepared for all of them, and we must prepare for all of them in the same way" at any time of the crisis. All kinds of drain are thus conflated. The ensuing problem is that the central bank may lose its way by ignoring the cause of drains and by missing the specific and appropriate response.

Second, Bagehot (1873, pp. 56-7) inferred that the central bank should apply the same expedient, the same level of interest rate, whatever the causes of the drain: "And at the rate of interest so raised, the holders - one or more-of the [banking] reserve must lend freely. Very large loans at very high rates are the best remedy for the worst malady of the money market when a foreign drain [of the metallic reserve] is added to a domestic drain." Again, all categories are here tangled and all banks may participate in lending operations. The same remedy (the very high rate) is to be applied for all kinds of drain, for the internal drain of the banking reserve as well as for the external drain of the metallic reserve. But, as Bagehot (1873, p. 319) came to recognize himself, "a uniform remedy for many diseases often ends by killing the patient." 
Third, Bagehot (1873, pp. 46, 173-4, 197) also inferred that the same sequence should be applied, whatever the circumstance: the rule of a high interest rate should be applied by "one bank or many banks [...] at the very beginning" of the crisis; the Bank rate "should be raised early in the panic"; the "usual defect" is that "the Bank of England does not raise the rate of interest sufficiently quickly" (see also Bagehot, 1874, p. 325). While Bagehot's rule prescribes that the Bank rate should be raised early on to a very high level in order to keep large reserves during crisis times, it implicitly assumes that the Bank rate was not previously high enough to maintain large reserves in ordinary times. It follows that, in strained conditions, the Bank had no time to appreciate the right sequence for an increase in its rate, and had finally no choice but to act promptly, and without discernment. This was precisely the case under the Peel system through the new discount policy: the interest rate set by the banking department of the Bank was set at a low level in normal times and reached a very high level during a panic.

The concern of keeping a large reserve applied with a very high rate in crisis times - and not with a fixed or above-the-market rate in normal times. Bagehot (1861, pp. 20-1; 1873, p. 115) repeatedly rejected the fixed Bank rate policy (that is, the $4 \%$ Bank rate policy) that the Bank of England applied under the Old system, and that Tooke advocated. However, Bagehot (1873, p. 320) unintentionally presented an interesting argument in favor of the fixed rate policy, by stating that: "the probable efflux of bullion from the Bank scarcely affects [the market rate] at all; even the real efflux affects it but little; if the open market did not believe that the Bank rate would be altered in consequence of such effluxes the market rate would not rise." Jeanne (1995, pp. 311-2) accurately interprets this passage as follows: "a gold outflow increased the market rate because market participants believed that the Bank would probably react by raising its rate. In other words, the market rate was strongly influenced by the expectation of the Bank reaction" (original italics). Actually, under the Peel system, the Bank applied an active rate policy and the market rate was in turn prompt to react, albeit nervously, to the Bank rate change. Under the Old system, in contrast, the Bank maintained its rate fixed as long as possible with the result that the Bank policy stabilized expectation in the market, which thereby was less prone to vary its rate drastically. Such a policy theoretically rests upon three of Tooke's propositions. ${ }^{17}$

\footnotetext{
${ }^{17}$ Bagehot never attempted to discuss the theory behind Tooke's propositions. Without explanation, Bagehot (1857c, p. 355) only asserted: "But at any rate it is hard on Mr. Tooke to say that a measure [keeping sufficient reserve] which used to be defended because his theory was mischievous and incomplete, was really intended to carry out that theory, which after all is complete."
} 


\subsubsection{Tooke's three propositions}

Bagehot's three assertions are worth comparing symmetrically to the three propositions developed by Tooke, Mill, and Fullarton in the 1840s and 1850s, namely: (1) the distinction between the causes of drain; (2) the distinction concerning the remedy; (3) the distinction concerning the sequence of the remedy.

First, the classical monetary theory, under which the Tooke-Mill-Fullarton analysis falls, integrates the cost-of-production theory of the value of the metallic money and stresses the role of the constraint of convertibility into specie of all bank issues (Niehans, 1987). Thereby, the pricespecie flow mechanism and the possibility of monetary causes of drain are dismissed so long as the specie regime and convertibility constraint prevail. Thus, under the specie regime at least, the classification of the real and financial causes of drain is decisive. The drain due to real factors such as a bad harvest is temporary, while the drain due to financial factors is more uncertain in scope and duration. The financial factors are not simply related to the domino effect. More dramatically, they are related to the fall in prices in some speculative asset markets, which impacts the balance sheet of banking institutions and worsens their liquidity if not their solvency. The ensuing downward spiral of market liquidity severely affects the banking system as a whole and its end remains uncertain (Skaggs, 1991, 1994; Le Maux, 2012, 2020).

Second, the distinction of the causes of drain is important with regard to the level of the Bank rate. The central bank does not apply the same expedient whatever the causes of the drain. It addressed the temporal drains due to real factors by keeping large metallic reserves in normal times and without raising its rate in difficult times. The central bank then addresses the uncertain drains due to financial factors by keeping large metallic reserves in normal times and also by raising moderately - and not too sharply - its rate in crisis times, in order to preserve the metallic reserve and to protect the solvency of banking institutions, at the same time.

Third, the distinction of the causes of drain is also decisive with regard to the sequence of the rise in the Bank rate. The central bank should increase its interest rate as a last resort-and not from the beginning of the crisis - once its metallic reserve critically attains a ceiling. The delay by the central bank before increasing its rate stabilizes participants' expectations, tempers uncertainty in the money market, and stabilizes the market rate. In sum, the expedient suggested by Bagehot entails the keeping of large reserves during a panic through a hasty rise in the Bank rate, whereas the policy proposed by Tooke involves the keeping of large reserve in normal times in order to maintain a moderate rate during the crisis.

The theoretical difference between Bagehot's assertions and Tooke's propositions lies partly in the question of the classification of the causes of drains and panics. In addition, two institutional differences lie in the acceptance or the rejection of the Peel system. The first concerns the mode of intervention of the lender of last resort. Bagehot's design prioritizes the mode of transfer of the banking reserve, while Tooke's design prioritizes the mode of issue of high-powered medium. 
Interestingly, Bagehot (1873, p. 56) himself pointed out the contradiction lying within the mode of transfer: "The holders of the reserve have, therefore, to treat two opposite maladies at onceone requiring stringent remedies, and especially a rapid rise in the rate of interest; and the other, an alleviative treatment with large and ready loans" (italics added). The mode of issue from the central bank escapes from such a contradiction.

The second institutional difference concerns the organization of the functions of the central bank. In Bagehot's (1866e, p. 19) view, "it is a serious difficulty that the same bank which keeps the ultimate reserve should also have the duty of lending in last resort. The two functions are in practice inconsistent - one prescribes keeping money, and the other prescribes the parting with money." In Tooke's mind, far from being a serious difficulty, it is a consistent design once the interest rate policy stands between the other two functions in accordance with the system of union of the functions of central banking. The metallic reserve helps to cope with external drains due to both real and financial factors; the central bank accumulates large metallic reserves by keeping its rate fixed in normal times (that is, above the market rate); the central bank acts as the lender of last resort by liberally providing high-powered medium against acceptable securities and at a moderate rate (that is, below the market rate). Far from being inconsistent, the three functions are thus integrated.

\section{Conclusion}

"Lending freely against good collateral at a high rate" was not a doctrine that Walter Bagehot could have discovered in 1873 after decades of obscurantism. The directors of the Bank of England witnessed how the Old Lady applied the policy of "lending liberally against acceptable collateral" from the 1825 crisis onwards. The practice of "lending at a high rate" appeared under the Peel system from the 1847 crisis onwards. So what appears as particular to Walter Bagehot's Lombard Street is the justification of the rule of a "very high" rate. Bagehot's rule of Bank rate roughly following the market rate downwards and upwards tended to accentuate the financial cycle (procyclicality) - while Tooke's rule of Bank rate above/below the market rate in normal/crisis times contributed to smoothing the financial cycle (contra-cyclicality). More precisely, from the domestic viewpoint, the Bank rate should be very high (that is, higher than the market rate) in order to incite banks to find liquidity first in the money market before asking for central bank liquidity - while Thomas Tooke advocated the "moderate rate" rule (that is, lower than the market rate) in order to mitigate the collapse of asset prices within financial markets, and to avoid a coordination problem within the market of funding liquidity. From the external viewpoint, the Bank rate should be set higher in crisis times in order to trigger a downturn in credit and prices, and secure an inflow of bullion, irrespective of the cause of the external drains - while Tooke advocated a moderate rise in the Bank rate in order to counteract external drains due to financial factors only. From the dynamic point of view, the Bank should raise its rate at the beginning of the crisis in order to protect its metallic reserve-while, for Tooke, the Bank should raise its rate only in last resort inasmuch as the policy of fixed and above-the-market rate in normal times contributed 
to build large metallic reserves beforehand. All in all, the Bank policy under the Peel system and Bagehot's rule was not the only option under the classical specie regime. The Bank of England implemented the fixed rate policy under the Old system as witnessed by Horsley Palmer at the parliamentary inquiries. At the same time, Thomas Tooke developed the classical central banking theory two decades before the publication of Lombard Street. New generations of Bank directors and writers, including Thomson Hankey and Walter Bagehot, took the Bank policy under the Peel system for granted. Hankey wanted to maintain the letter and the spirit of the 1844 Act intact, while Bagehot wanted to resort to palliatives. Although the Bagehot-Hankey quarrel makes sense within the 1866-1873 period, once the panorama becomes is widened, such quarrelling appears petty and consigned to Victorian times. 


\section{Bagehot's publications on currency and banking}

Bagenot Walter, 1848, “The Currency Monopoly", Prospective Review, vol. 5, no. 15, pp. 297 337. In Bagehot (1978), The Collected Works of Walter Bagehot, volume 9, pp. 235-271.

BAGEHOT Walter, 1857a, "The General Aspect of the Banking Question", The Economist, vol. 15, February 7, pp. 141-143. In Walter Bagehot, 1978, The Collected Works, volume 9, pp. 318-325.

Bagehot Walter, 1857b, "Recent Experience Opposed to the Theory of the Act of 1844", The Economist, vol. 15, February 14, pp. 168-170. In Walter Bagehot, 1978, The Collected Works, volume 9, pp. 326-332.

BAGEHOT Walter, 1857c, "The Act of 1844 and the Convertibility of the Note", The Economist, vol. 15, May 16, pp. 534-535. In Walter Bagehot, 1978, The Collected Works, volume 9, pp. 351356.

BAGEHOT Walter, 1857d, "The New Mode of Defending the Act of 1844", The Economist, vol. 15, June 6, pp. 617-618. In Walter Bagehot, 1978, The Collected Works, volume 9, pp. 357-360.

BAGEHOT Walter, 1857e, “The Original Reason for the Act of 1844”, The Economist, vol. 15, July 4, pp. 730-731. In Walter Bagehot, 1978, The Collected Works, volume 9, pp. 361-364.

BaGeHOT Walter, 1857f, "On the Insufficiency of the Bank Reserve", The Economist, vol. 15, November 28, pp. 1316-1318. In Walter Bagehot, 1978, The Collected Works, volume 9, pp. 370377.

BAGEHOT Walter, 1857g, "The Insufficiency of the Bank Reserve Aggravated by Sir Robert Peel's Act", The Economist, volume 15, December 5, pp. 1345-1346. In Walter Bagehot, 1978, The Collected Works, volume 9, pp. 378-380.

BAGEHOT Walter, 1857h, "What is the Proper Reserve of the Bank of England", The Economist, vol. 16, April 3, pp. 365-366. In Walter Bagehot, 1978, The Collected Works, volume 9, pp. 381386.

BAGEHOT Walter, 1858, “The Monetary Crisis of 1857”, National Review, vol. 6, January, pp. 228-253. In Walter Bagehot, 1978, The Collected Works, volume 10, pp. 49-87.

BAGEHOT Walter, 1861, "The Duty of the Bank of England in Times of Quietude", The Economist, vol. 19, September 14, pp. 1009. In Walter Bagehot, 1978, The Collected Works, volume 10, 1978, pp. 20-22.

BAGEHOT Walter, 1864a, "What the Money Market is, and Why It is so Changeable", The Economist, vol. 22, September 3, pp. 1105-1107. In Walter Bagehot, 1978, The Collected Works, volume 9, pp. 421-426. 
BAGEHOT Walter, 1864b, “The Money Market”, The Economist, vol. 22, September 24, pp. 11931195. In Walter Bagehot, 1978, The Collected Works, volume 9, pp. 427-434.

BAGEHOT Walter, 1864c, "What a Panic is and How it Might be Mitigated", The Economist, vol. 22, October 1, pp. 1221-1222. In Walter Bagehot, 1978, The Collected Works, volume 9, pp. 435439.

BAGEHOT Walter, 1864d, “The Very Particular Position of the Bank of England”, The Economist, vol. 22, October 8, pp. 1249-1251. In Walter Bagehot, 1978, The Collected Works, volume 9, pp. 440-446.

BAgEhOt Walter, 1864e, “An Estimate of Peel's Act”, The Economist, vol. 22, October 22, pp. 1305-1307. In Walter Bagehot, 1978, The Collected Works, volume 9, pp. 447-455.

BAGEHOT Walter, 1864f, "The Theoretical Arguments by Which the Act of 1844 was Originally Justified”, The Economist, vol. 22, November 5, pp. 1369-1372. In Walter Bagehot, 1978, The Collected Works, volume 9, pp. 456-464.

BAgEHOT Walter, 1864g, "The Great Truth to Which the Theory of the Act of 1844 is an Approximation, and for Which it is a Mistake", The Economist, vol. 22, November 12, pp. 13991400. In Walter Bagehot, 1978, The Collected Works, volume 9, pp. 465-471.

BAGEHOT Walter, 1864h, "French Criticism of the Act of 1844", The Economist, vol. 22, November 19, pp. 1425-1426. In Walter Bagehot, 1978, The Collected Works, volume 9, pp. 472475.

BAGEHOT Walter, 1865, "Should There be a Single Issuer of Bank Notes or Many Issuers", The Economist, vol. 23, January 28, pp. 95-97. In Walter Bagehot, 1978, The Collected Works, volume 9, pp. 490-494.

BAgehot Walter, 1866a, "What a Panic is and How it Might be Mitigated", The Economist, vol. 24, May 12, pp. 554-555. In Walter Bagehot, 1978, The Collected Works, volume 10, pp. 88-92.

BAgehot Walter, 1866b, “The Panic”, The Economist, vol. 24, May 19, pp. 581-583. In Walter Bagehot, 1978, The Collected Works, volume 10, pp. 93-100.

BAGEHOT Walter, 1866c, “The Practical Effect of the Act of 1844”, The Economist, vol. 24, May 26, pp. 614-615. In Walter Bagehot, 1978, The Collected Works, volume 10, pp. 101-103.

BAGEHOT Walter, 1866d, "Is it Better That The Banking Reserve of a Country Should be Kept in a Single Bank or be Distributed between Several Banks?" The Economist, vol. 24, August 25, pp. 995-996. In Walter Bagehot, 1978, The Collected Works, volume 11, pp. 14-17.

BAGEHOT Walter, 1866e, "One Banking Reserve or Many?" The Economist, vol. 24, September 1, pp. 1025-1026. In Walter Bagehot, 1978, The Collected Works, volume 11, pp. 18-21. 
BAGEHOT Walter, 1866f, "The Great Importance of the Late Meeting of the Proprietors of the Bank of England", The Economist, vol. 24, September 22, pp. 1105-1106.

BAGEHOT Walter, 1866g, "A Bank Director on Banking and the Currency", The Economist, vol. 24, December 8, pp. 1418-1419.

BAGEHOT Walter, 1867a, “The 'National Bank' System of the United States: Its Progress and Effects", The Economist, vol. 25, June 8, pp. 638-640. In Walter Bagehot, 1978, The Collected Works, volume 10, pp. 389-395.

BAgEHOT Walter, 1867b, "The Position of the Bank of England in the Money Market", The Economist, vol.25, September 28, pp. 1093-1094. In Walter Bagehot, 1978, The Collected Works, volume 11, pp. 22-26.

BAgEHOT Walter, 1869a, "Will the Money Market Take Care of Itself", The Economist, vol. 27, April 17, pp. 437-438. In Walter Bagehot, 1978, The Collected Works, volume 11, pp. 27-32.

BAGEHOT Walter, 1869b, "The Government and the Bank of England", The Economist, vol. 27, June 5, pp. 654-655. In Walter Bagehot, 1978, The Collected Works, volume 11, pp. 33-36.

BAGEHOT Walter, 1871, "The Reduction in the Bank Rate of Discount", The Economist, vol. 29, November 18, pp. 1393-1394. In Walter Bagehot, 1978, The Collected Works, volume 11, pp. 3740 .

BAGEHOT Walter, 1873, Lombard Street: A Description of the Money Market, London, Henry S. King.

BAGEHOT Walter, 1874, “The 'Bankers' Balances' and the Bank of England”, The Economist, vol. 32, December 19, pp. 1505-1506. In Walter Bagehot, 1978, The Collected Works, volume 10, pp. 322-325.

BAGEHOT Walter, 1875, "The Lesson of Recent Events in the Money Market", The Economist, vol. 33, July 10, pp. 805-806. In Walter Bagehot, 1978, The Collected Works, volume 11, pp. 4853.

BAGEHOT Walter, 1876, “The Use of a Large Bank Reserve”, The Economist, vol. 34, April 22, pp. 477-478. In Walter Bagehot, 1978, The Collected Works, volume 11, pp. 54-56.

BAgEhOt Walter, 1978, The Collected Works of Walter Bagehot - The Economic Essays, in Norman St John-Stevas (Ed.), volumes 9-11, London, The Economist. 


\section{References}

ACHARYA Viral V. and BACKus David K. 2009. "Private Lessons for Public Banking: The Case for Conditionality in LOLR Facilities", in V. V. Acharya and M. Richardson (eds.), Restoring Financial Stability: How to Repair a Failed System, New York, John Wiley, pp. 305-321.

Anson Mike, Bholat David, Miao Kang and RYLAnd Thomas. 2017. “The Bank of England as Lender of Last Resort: New Historical Evidence from Daily Transactional Data”, Bank of England Staff Working Paper, no. 691, November.

Anson Mike, Bholat David, MiaO Kang, RiEDER Kilian and RYLAnd Thomas. 2019. “The Bank of England and Central Bank Credit Rationing during the Crisis of 1847: Frosted Glass or Raised Eyebrows", Bank of England Staff Working Paper, no. 794, April.

AntinOlfi Gaetano, HuYbens Elisabeth and KeISTER Todd. 2001. "Monetary Stability and Liquidity Crises: The Role of the Lender of Last Resort", Journal of Economic Theory, vol. 99, no. 1-2, pp. 187-219.

ARnON Arie. 2011. Monetary Theory and Policy from Hume and Smith to Wicksell: Money, Credit, and the Economy, Cambridge, Cambridge University Press.

BANK OF ENGLAND. 1866. "Meeting of the proprietors of the Bank of England, September 13, 1866”, The Economist, vol. XXIV, September 22, pp. 1105-6.

Bernanke Ben S. 2008. "Liquidity Provision by the Federal Reserve", Speech at the Federal Reserve Bank of Atlanta Financial Markets Conference, Sea Island, Georgia, May 13.

Bernanke Ben S. 2013. The Federal Reserve and the Financial Crisis, Princeton and Oxford, Princeton University Press.

Bignon Vincent, Flandreau Marc and Ugolini Stefano. 2011. "Bagehot for Beginners: The Making of Lender-of-Last-Resort Operations in the Mid-Nineteenth Century", Economic History Review, vol. 65, no. 2, pp. 580-608.

BORDO Michael D. 1990. "The Lender of Last Resort: Alternative Views and Historical Experience”, Economic Review, Federal Reserve of Richmond, vol. 76, no. 1, pp. 18-29.

BORDO Michael D. 1998. "The Financial Crisis of 1825 and the Restructuring of the British Financial System: Commentary", Federal Reserve of Saint Louis Review, vol. 80, no. 3, pp. 7782.

BORDO Michael D. 2014. "Rules for a Lender of Last Resort: An Historical Perspective", Journal of Economic Dynamics and Control, vol. 49, December, pp. 126-134. 
BRADFORD Gamaliel. 1874. "Lombard and Wall Streets", North American Review, vol. 119, no. 245, pp. 331-358.

BuITER Willem H. 2008. "Central Banks and Financial Crisis", Maintaining Stability in a Changing Financial System Symposium, Federal Reserve Bank of Kansas City, Jackson Hole, Wyoming, August, pp. 495-633.

Bullion REPORT. 1810. Report from the Select Committee on the High Price of Gold Bullion, London, House of Commons, volume III (349).

Castiglionesi Fabio and Wagner Wolf. 2012. "Turning Bagehot on His Head: Lending at Penalty Rates When Banks Can Become Insolvent”, Journal of Money, Credit, and Banking, vol. 44, no. 1, pp. 201-219.

CAPIE Forrest. 2007. “The Emergence of the Bank of England as a Mature Central Bank", in F. H. Capie and G. E. Wood (eds), The Lender of Last Resort, New York, Routledge.

ClaAssen Emil-Maria. 1985. "The Lender-of-Last-Resort Function in the Context of National and International Financial Crises", Weltwirtschaftliches Archiv/Review of World Economics, vol. 121, no. 2, pp. 217-237.

Collins Michael. 1992. "The Bank of England as Lender of Last Resort, 1857-1878”, Economic History Review, vol. XVL, no. 1, pp. 145-153.

CORRIGAN E. Gerald. 1990. "Statement before U.S. Senate Committee on Banking, Housing, and Urban Affairs", U.S. Senate, Washington D.C., May.

CROCKETT Andrew. 1997. “The Theory and Practice of Financial Stability", Essays In International Finance, no. 203, Princeton, Princeton University.

DAVUTYAN Nuhran and William R. PARKE, 1995, "Operations of the Bank of England, 1890-1908:

A Dynamic Probit Approach”, Journal of Money, Credit and Banking, vol. 27, no. 4, pp. 10991112.

DomAnski Dietrich, MOESSNER Richhild and NelsOn William. 2014. "Central Banks as Lenders of Last Resort : Experiences during the 2007-10 Crisis and Lessons for the Future", Bank for International Settlement Papers, no. 79, September.

FETTER Frank W. 1965. The Development of British Monetary Orthodoxy, 1797-1875, Cambridge, Harvard University Press.

FETTER Frank W. 1967. “An Historical Confusion in Bagehot's Lombard Street”, Economica, vol. 34, no. 133 , pp. 80-83. 
FrEemAn Scott. 1996. “The Payment System, Liquidity and Rediscounting”, Americal Economic Review, vol. 86, no. 5, pp. 1126-1138.

FlandREAU Marc and UgOLINI Stefano. 2013. "Where It All Began: Lending of Last Resort and the Bank of England during the Overend-Gurney Panic of 1866", in M. D. Bordo and W. Roberts (eds.), The Origins, History, and Future of the Federal Reserve, Cambridge, Cambridge University Press, pp. 113-161.

FreiXas X., Giannini C., Hoggarth G. and Soussa F. 2000. "Lender of Last Resort: What Have We Learned Since Bagehot?” Journal of Financial Services Research, vol. 18, no. 1, pp. 63-84.

FreiXas X., Martin A. and SkeIE D. 2011. "Bank Liquidity, Interbank Markets, and Monetary Policy”, Review of Financial Studies, vol. 24, no. 8, pp. 2656-2692.

Freixas X., PARigi B. and Rochet Jean-Charles. 2004. "The Lender of Last Resort: A TwentyFirst Century Approach", Journal of the European Economic Association, vol. 2, no. 6, pp. 10851115 .

FULLARTON John. 1845. On the Regulation of Currencies, second edition, London, John Murray.

Garcia Gillian and Plautz Elizabeth. 1988. The Federal Reserve: Lender of Last Resort, Cambridge MA, Ballinger.

GiANNINI Curzio. 1999. "Enemy of None but a Common Friend of All? An International Perspective on the Lender-of-last-resort Function”, Essays in International Finance, no. 214, June.

GiAnNini, Curzio, 2011. The Age of Central Banks, Cheltenham, Edward Elgar.

Gilbart James W. 1841. "The Currency: Banking”, Westminster Review, vol. XXXV, JanuaryApril: 89-131.

GoODFRIEND, Marvin and KING, Robert G. 1988. "Financial Deregulation, Monetary Policy and Central Banking”, Economic Review, Federal Reserve Bank of Richmond, vol. 74, no. 3, 3-22.

Goodhart A. E. Charles. 1988. The Evolution of Central Banks, Cambridge, MIT Press.

GoOdHART A. E. Charles. 1994. "Game Theory for Central Bankers: A Report to the Governor of the Bank of England”, Journal of Economic Literature, vol. 32, no. 1, pp. 101-114.

Goodhart A. E. Charles. 1999. "Myths About the Lender of Last Resort", International Finance, vol. 2, no. 3, pp. 339-360.

GrANT, James. 2019. Bagehot: The Life and Times of the Greatest Victorian, New York, W. W. Norton. 
Grossman Richard S. and RocKOFF Hugh. 2015. "Fighting the Last War: Economists on the Lender of Last Resort", NBER Working Papers, no. 20832, January.

GutTentag, Jack and HerRing Richard. 1983. "The Lender-of-Last-Resort Function in an International Context", Princeton University, Essays in International Finance, no. 151.

HANKEY Thomson. 1867. The Principles of Banking, Its Utility and Economy; With Remarks on the Working and Management of the Bank of England, London, Effingham Wilson.

HAWTREY Ralf G. 1932. The Art of Central Banking, London, Longmans.

Hetzel Robert L., 1987, "Henry Thornton: Seminal Monetary Theorist and Father of the Modern Central Bank”, Economic Review, Federal Reserve Bank of Richmond, vol. 73, no. 4, pp. 3-16.

HIRSCH Fred. 1977. “The Bagehot Problem”, The Manchester School, vol. 45, no. 3, pp. 241-257.

Hogan Thomas L., Le Linh and SAlter Alexander W. 2015. "Ben Bernanke and Bagehot's Rule”, Journal of Money, Credit and Banking, vol. 47, no. 2-3, pp. 333-348.

HoRSEFIELD J. Keith. 1944. "The Origins of the Bank Charter Act, 1844”, Economica, vol. 11, no. 44, pp. 180-189.

Humphrey Thomas M. 1975. "The Classical Concept of the Lender of Last Resort", Economic Review, Federal Reserve Bank of Richmond, vol. 61, no. 1, pp. 2-9.

HuMPHREY Thomas M. 1989. "Lender of Last Resort: The Concept in History", Economic Review, Federal Reserve Bank of Richmond, vol. 75, no. 2, pp. 8-16.

HumPhrey Thomas M. and KelEHER Robert E. 1984. "The Lender of Last Resort: A Historical Perspective", Cato Journal, vol. 4, no. 1, 275-318.

JEANNE Olivier. 1995. "Monetary Policy in England 1893-1914: A Structural VAR Analysis", Explorations in Economic History, vol. 32, no. 3, pp. 302-326.

JEVONS W. Stanley. 1875. Money and the Mechanism of Exchange, New York, Appleton.

KAUfMAN George G. 1991. "Lender of Last Resort: A Contemporary Perspective", Journal of Financial Services Research, vol. 5, no. 2, pp. 95-110.

KELEHER, Robert. 1999. “An International Lender of Last Resort, the IMF, and the Federal Reserve”, Joint Economic Committee, United States Congress, Washington DC, February.

KEYNES John M. 1915. “The Works of Bagehot”, Economic Journal, vol. 25, no. 99, pp. 369-375. 
KInDleberger, Charles P. 1980. "Review of The Collected Works of Walter Bagehot: The Economic Essays. Edited by Norman St John-Stevas. Introduction by R. S. Sayers", Journal of Economic Literature, vol. 18, no. 1, pp. 118-121.

Kindleberger, Charles P. 1983. "Key Currencies and Financial Centres", in F. Machlup, G. Fels and H. Müller-Groeling (eds), Reflections on a Troubled World Economy: Essays in Honor of Herbert Giersch, London, Macmillan Press, St. Martin's Press, New York, pp. 75-90.

KIndLEBerger, Charles P. 1996. “The Lender of Last Resort: Pushing the Doctrine Too Far?”, in Forrest Capie and Geoffrey E. Wood (eds.), Monetary Economics in the 1990s, Basingstoke, Macmillan Press, pp. 122-136.

LAIDLER David. 1988. "British Monetary Orthodoxy in the 1870s", Oxford Economic Papers, vol. 40, no. 1, pp. 74-109.

LAIDLER David. 1991. The Golden Age of the Quantity Theory: The Development of Neoclassical Monetary Economics, 1870-1914, New York, Philip Allan.

LAIDLER David. 2000. "Highlights of the Bullionist Controversy", Institute for Research in Economic History, Stockholm School of Economics, Research Report no. 13.

LAIDLER, David. 2004a. "Two Views of the Lender of Last Resort: Thornton and Bagehot", in Macroeconomics in Retrospect: The Selected Essays of David Laidler, Cheltenham, Elgar, pp. 4056.

LAIDLER, David. 2004b. "Central Bank as the Lender of Last Resort - Trendy or Passe", Conference on Central Banking and the Financial System, National Bank of Poland, Warsaw, October 7-8.

LE MAuX Laurent. 2012. "The Banking School and the Law of Reflux in General”, History of Political Economy, vol. 44, no. 4, pp. 595-618.

LE MAUX Laurent. 2018. "Banque centrale et finance: la Banque d'Angleterre, le taux d'intérêt et le Bank Act de 1844", Revue Economique, vol.69, n²4,pp.541-573. English translation: "Central Banking and Finance: the Bank of England and the Bank Act of 1844" (May 2020) available at: https://hal.archives-ouvertes.fr/hal-02854521/document

Le MaUX Laurent. 2019. "Thomas Tooke and the Classical Theory of Central Banking", Unpublished Manuscript.

Le Maux Laurent. 2020. "The Classical Monetary Theory on Bank Liquidity and Finance", Oxford Economic Papers, vol. 72, no. 3, pp. 692-709.

LE MAUX Laurent. 2021. “The Endogeneity of Central Banking”, Unpublished Manuscript. 
LOYD Samuel Jones [Lord Overstone]. 1844. Thought on the Separation of the Departments of the Bank of England, London, Pelham Richardson.

LOYD Samuel Jones [Lord Overstone]. 1857. Tracts and Other Publications on Metallic and Paper Currency, J.R. McCulloch (Ed.), London, Longman.

MAdigAn Brian F. 2009. "Bagehot's Dictum in Practice: Formulating and Implementing Policies to Combat the Financial Crisis", Financial Stability and Macroeconomic Policy, Economic Symposium Conference Proceedings, Federal Reserve Bank of Kansas City, pp. 169-189.

MARTIN Antoine. 2006. "Liquidity Provision versus Deposit Insurance: Preventing Bank Panics without Moral Hazard”, Economic Theory, vol. 28 no. 1, pp. 197-211.

MARTIN Antoine. 2009. "Reconciling Bagehot and the Fed's Response to September 11", Journal of Money, Credit and Banking, vol. 41, no. 2-3, pp. 397-415.

Mehrling, Perry S. 2011. The New Lombard Street: How the Fed Became the Dealer of Last Resort, Princeton, Princeton University Press.

MeHrLING, Perry S. 2019. "Review of James Grant's Bagehot: The Life and Times of the Greatest Victorian", Economic History Association, EH-Net, November. Available at: https://eh.net/book_reviews/bagehot-the-life-and-times-of-the-greatest-victorian/

Mehrling, Perry S., Zoltan Pozsar, James Sweeney, Dan NeIlson. 2014. "Bagehot Was a Shadow Banker: Shadow Banking, Central Banking, and the Future of Global Finance", in S. Classens, D. Evanoff, G. Kaufman, and L. Laeven (eds.), Shadow Banking Within and Across Borders, Hackensack, World Scientific Publishing, pp. 71-87.

Meltzer Allen H. 1986. "Financial Failures and Financial Policies", in George G. Kaufman and Roger C. Kormendi (eds.), Deregulating Financial Services, Cambridge Massachusetts, Ballinger, pp. 79-96.

MiLl John Stuart. 1844. “The Currency Question”, Westminster Review, XLI, March-June: 579598.

MiLl John Stuart. 1848. Principles of Political Economy with Some of Their Applications to Social Philosophy, in J. M. Robson (Ed.), The Collected Works of John Stuart Mill, volumes II and III, Toronto, University of Toronto Press, 1965-1991.

MiLne Alistair and WoOd Geoffrey E. 2008. "Banking Crisis Solution Old and New", Review, Federal Reserve of Saint-Louis, vol. 90, no. 5, pp. 517-530.

MinTs Lloyd W. 1945, A History of Banking Theory in Great Britain and the United States, Chicago, Chicago University Press. 
MoORE, Gregory. 1996. "The Practical Economics of Walter Bagehot”, Journal of the History of Economic Thought, vol. 18, no. 2, pp. 229-49.

MOORE, Gregory. 1999. "Solutions to the Moral Hazard Problem Arising from the Lender-of-LastResort Facility”, Journal of Economic Surveys, vol. 13, no. 4, pp. 443-476.

NEWMARCH, William. 1866. “The Financial Pressure and Ten per Cent”, Fraser's Magazine, LXXIV (CCCCXL), pp. 229-242.

NIEHANS Jürg. 1987. "Classical Monetary Theory, New and Old", Journal of Money, Credit, and Banking, vol. 19, no. 4, pp. 409-424.

Norman George W. 1841. Letter to Charles Wood, Esq., M.P. on Money, and the Means of Economizing the Use of It, London, Pelham Richardson.

PALGRAVE R. H. Inglis. 1910. "The History of the Separation of the Departments of the bank of England", National Monetary Commission, 61st Congress, 2nd Session, vol. 18, doc. 492, Washington D.C., Government Printing Office, pp. 149-261.

PALGRAVE R. H. Inglis. 1874. “Banking”, Fortnightly Review, no. 85, January, pp. 92-108.

PARLIAMENTARY PAPERS (Commons). 1848. Reports from the Select Committee on Commercial Distress with the Minutes of Evidence, Appendix, and Index, London, House of Commons, volume 8 , parts $1-2$.

PARLIAMENTARY PAPERS (Lords). 1848. Report from the Lords' Secret Committee appointed to inquire into the Cause of the Distress among Commercial Classes, and how far it has been affected by the Laws for regulating the Issue of Bank Notes payable on Demand, London, House of the Lords, volume 8, part 3.

PARLIAMENTARY PAPERS. 1840. Report from the Select Committee Appointed to Inquire into the Effects Produced on the Circulation of the Country by the Various Banking Establishments Issuing Notes Payable on Demand, London, House of Commons, volume 4.

PARLIAMENTARY PAPERS. 1857. Report from the Select Committee on Bank Acts together with the Proceedings of the Committee, Minutes of Evidence, Appendix and Index, London, House of Commons, volume 10, parts 1-2.

PARLIAMENTARY PAPERS. 1858. Report from the Select Committee Appointed to Inquire into the Operation of the Bank Acts, and into the Causes of the Recent Commercial Distress, London, House of Commons, volume 5.

PARLIAMENTARY PAPERS (PP). 1875. Report from the Select Committee on Banks of Issue, Londres, House of Commons, volume 9. 
PARnell Henry. 1827. Observations on Paper Money, Banking, and Overtrading, London, James Ridgway.

RIST Charles. 1940. A History of Monetary and Credit Theory from John Law to the Present Day, London, Macmillan.

RocheT Jean-Charles and VIVES Xavier. 2004. "Coordination Failures and the Lender of Last Resort: Was Bagehot Right After All?”, Journal of the European Economics Association, vol. 2, no. 6, pp. 1116-1147.

ROCKOFF Hugh. 1986. "Walter Bagehot and the Theory of Central Banking”, in F. Capie \& G.E. Woods, Financial Crises and the World Banking System, Macmillan, London, pp. 160-180.

RePUllo, Rafael. 2000. "Who Should Act as Lender of Last Resort? An Incomplete Contracts Model”, Journal of Money, Credit, and Banking, vol. 32, no. 3, pp. 580-605.

Santos, Joao A. C. 2006. "Insuring Banks Against Liquidity Shocks: The Role of Deposit Insurance and Lending of Last Resort”, Journal of Economic Surveys, vol. 20, no. 3, pp. 459-482.

SAYERS, Richard S. 1936. The Bank of England 1890-1914, Cambridge, Cambridge University Press.

SAYERS, Richard S. 1951. "The Development of Central Banking After Bagehot", Economic History Review, vol. 4, no. 1, pp. 109-116.

SCHWARTZ, Anna J. 1986. "Real and Pseudo-Financial Crises", in F. Capie and G. E. Wood (eds.), Financial Crises and the World Banking System, London, Macmillan, 11-31.

SELGIN George A. 1989. "Legal Restrictions, Financial Weakening, and the Lender of Last Resort”, Cato Journal, vol. 9, no. 2, pp. 429-469.

SElgin George A. and White Lawrence H. 1994. "How Would the Invisible Hand Handle Money", Journal of Economic Literature, vol. 32, no. 4, pp. 1718-1749.

SHEND A. 1991. "Role of the Central Bank in Banking Crisis: An Overview", in P. Downes and R. Vaez-Zadeh (eds.), The Evolving Role of Central Banks, International Monetary Fund, Washington D. C., pp. 193-217.

SKAGgs Neil T. 1991. "John Fullarton's Law of Reflux and Central Bank Policy”, History of Political Economy, 23.3: 457-480.

SkAGgS Neil T. 1994. "The Place of J. S. Mill in the Development of British Monetary Orthodoxy”, History of Political Economy, vol. 26, no. 4, pp. 539-567.

SKAGGS, Neil T. 1995. "Henry Thornton and the Development of Classical Monetary Economics", Canadian Journal of Economics, vol. 28, no. 4b, pp. 1212-1227. 
SLEET Christopher and Bruce D. SMITH B. D. 2000. "Deposit Insurance and Lender-of-Last-Resort Functions", Journal of the Money, Credit, and Banking, vol. 32, no. 3, pp. 518-575.

THORNTON Henry. 1802. An Enquiry into the Nature and Effects of the Paper Credit of Great Britain, in F. A. von Hayek (ed.), London, Allen and Unwin, 1939.

ToOKE Thomas. 1840. A History of Prices and of the State of the Circulation, 1838-1839, volume III, London, Longmans.

ToOKe Thomas. 1844. An Inquiry into the Currency Principle, second edition, London, Longmans.

TOOKE Thomas. 1848. A History of Prices and of the State of the Circulation, 1839-1847, volume 4, London, Longmans.

Tooke Thomas and Newmarch William. 1857. A History of Prices and of the State of the Circulation, 1848-1856, volumes 5 and 6, London, Longmans.

TORRENS Robert. 1844. An Inquiry into the Practical Working of the Proposed Arrangements for the Renewal of the Charter of the Bank of England, and the Regulation of the Currency, second edition, London, Smith \& Elder.

TORRENS Robert. 1848. The Principles and Practical Operation of Sir Robert Peel's Bill of 1844 Explained, and Defended against the Objections of Tooke, Fullarton, and Wilson, London, Longman.

TORRENS Robert. 1857. The Principles and Practical Operation of Sir Robert Peel's Bill of 1844 Explained, and Defended against the Objections of Tooke, Fullarton, and Wilson, second edition, London, Longman.

TREASURY COMMITTEE. 2007. "Memorandum from the Bank of England", The Run on the Rock, London, House of Commons Treasury Committee, Fifth Report of Session 2007-2008, volume 2, pp. 214-217.

VINER Jacob. 1937. Studies in the Theory of International Trade, London, Harper.

WILSON James. 1847. Capital, Currency, and Banking, London, The Economist.

Wood Elmer. 1939. English Theories of the Central Banking Control, 1819-1858, Cambridge, Harvard University Press.

Wood Geoffrey E. 2000. "The Lender of Last Resort Reconsidered", Journal of Financial Services Research, vol. 18, no. 2/3, pp. 203-227. 
